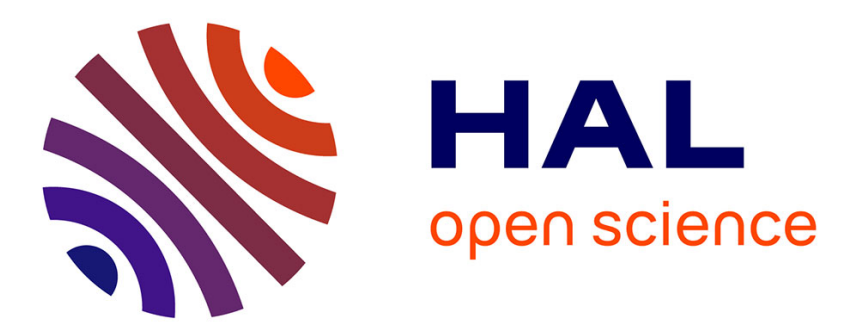

\title{
Synthesis and phloem mobility of acidic derivatives of the fungicide fenpiclonil
}

Jean-François Chollet, Françoise Rocher, Cyril Jousse, Céline

Delétage-Grandon, Georges Bashiardes, Jean-Louis Bonnemain

\section{- To cite this version:}

Jean-François Chollet, Françoise Rocher, Cyril Jousse, Céline Delétage-Grandon, Georges Bashiardes, et al.. Synthesis and phloem mobility of acidic derivatives of the fungicide fenpiclonil. Pest Management Science, 2005, 60, pp.1063-1072. 10.1002/ps.906 . hal-00107365

\section{HAL Id: hal-00107365 \\ https://hal.science/hal-00107365}

Submitted on 4 Jul 2019

HAL is a multi-disciplinary open access archive for the deposit and dissemination of scientific research documents, whether they are published or not. The documents may come from teaching and research institutions in France or abroad, or from public or private research centers.
L'archive ouverte pluridisciplinaire HAL, est destinée au dépôt et à la diffusion de documents scientifiques de niveau recherche, publiés ou non, émanant des établissements d'enseignement et de recherche français ou étrangers, des laboratoires publics ou privés. 


\title{
Synthesis and phloem mobility of acidic derivatives of the fungicide fenpiclonil
}

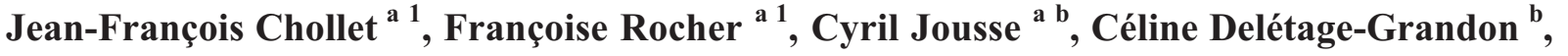 \\ Georges Bashiardes ${ }^{a}$ and Jean-Louis Bonnemain ${ }^{b}$ * \\ a Laboratoire «Synthèse et Réactivité des Substances Naturelles», Unité Mixte de Recherche \\ CNRS 6514, 40, av. du Recteur Pineau, 86022 Poitiers cedex, France \\ ${ }^{\mathrm{b}}$ Laboratoire «Transport des Assimilats», Unité Mixte de Recherche CNRS 6161, 40, av. du \\ Recteur Pineau, 86022 Poitiers cedex, France
}

\begin{abstract}
A series of derivatives of the phenylpyrrole fungicide fenpiclonil was synthesized in which a carboxyl group was present at various sites of this non-phloem mobile molecule. Using the Kleier model, all these acidic analogues were predicted to be moderately phloem mobile, especially the N-substituted derivatives. One of these latter molecules, $\mathrm{N}$-carboxymethyl-3-cyano-4-(2,3dichlorophenyl)pyrrole, exhibited some fungicidal activity on the pathogenic fungus Eutypa lata, and was then tested as a phloem-mobile pesticide in the Ricinus system. The compound was indeed mobile in the sieve tubes and was not degraded to fenpiclonil in the phloem sap under our experimental conditions. Its concentration in the sap was closely correlated to the percentage of the undissociated form of the molecule in the external medium, and was similar under acidic conditions (external pH 4.6 to 5.0) to that of the herbicide glyphosate.
\end{abstract}

Keywords : phenylpyrroles, fenpiclonil, systemicity, phloem mobility, antifungal activity, Eutypa lata

* Correspondence to : Jean-Louis Bonnemain, Laboratoire «Transport des Assimilats», Unité Mixte de Recherche CNRS 6161, Université de Poitiers, 40, av. du Recteur Pineau, 86022 Poitiers cedex, France

E-mail : j1.bonnemain@voila.fr

\footnotetext{
${ }^{1}$ These authors contributed equally to the paper
} 


\section{INTRODUCTION}

The movement of xenobiotics within plants is, as a general rule, governed by their physicochemical properties, more precisely their lipophilicity (assessed as the 1-octanol/water partition coefficient, $\log \mathrm{K}_{\mathrm{ow}}$ ) and pKa values. ${ }^{1-6}$ It also depends on the parameters of the plant vascular system. ${ }^{1,6,7}$

Except for a few xenobiotic molecules (e.g. the nematicide oxamyl), the phloem mobile pesticides are herbicides. Most of these are either acidic molecules or esters that can be hydrolyzed to an acid once they are in the plant tissues. ${ }^{6}$ Transport across the plasma membrane occurs by diffusion of the lipophilic undissociated form of the acid from the phloem apoplast $(\mathrm{pH} \approx 5.0)$. Once inside the phloem symplast $(\mathrm{pH} \geq 7.5)$, these molecules dissociate into hydrophilic anions that are generally unable to diffuse back through the plasma membrane. Thus, weak-acid herbicides can be loaded into the phloem and then transported within the plant. ${ }^{1,8-10}$ In addition, phloem loading of auxinic herbicides (e.g. 2,4D) involves two mechanisms, the ion-trap mechanism as described above, and an active process mediated by a carrier. ${ }^{11,12}$

The term "systemic fungicide" applies usually to fungicides that are mobile only in the apoplastic compartment. ${ }^{6,13}$ They include benzimidazoles, thiophanates, anilides, sterol-biosynthesis inhibitors, carbamates and strobilurins. ${ }^{14}$ The phloem mobility of these molecules is either undetectable or minute. In the past, the acylalanines have excited some researchers over the potential ability of basipetal phloem transport to control root pathogens. However, only trace amounts of label were observed in the root system after foliar applications of ${ }^{14} \mathrm{C}$-metalaxyl. ${ }^{13,15}$ Since metalaxyl is an ester, the ester group was hydrolyzed to produce a weak acid. The apparent phloem mobility was thus due to the free acid of metalaxyl, but which was no longer a fungicide. ${ }^{13}$

The development of phloem mobile or ambimobile fungicides that can be applied to foliage to control root or vascular system pathogens has long been needed. However, as noted by Kleier and al., ${ }^{6}$ the molecular modifications which enhance phloem systemicity have the unintended consequence of suppressing biological activity and this is particularly true for fungicides. 
The purpose of this work was i) to synthesize ionizable analogues of fenpiclonil, a non-phloem mobile fungicide, and ii) to study their properties in terms of biological activities and phloem mobility. Fenpiclonil was the first phenylpyrrole fungicide, developed by Ciba-Geigy (now Syngenta) for seed treatment in cereals. ${ }^{16,17}$ It is an analog of the antifungal metabolite pyrrolnitrin, which is produced by several Pseudomoniae. It has very low oral toxicity for rats $\left(>5000 \mathrm{mg} \mathrm{kg}^{-1}\right)$. Various Ascomycota, Basidiomycota and Deuteromycota are sensitive to this fungicide. ${ }^{18}$ Although no longer commercialized, fenpiclonil was selected at this stage of the work because of the possibilities of adding a carboxyl group at various sites in the molecule.

\section{EXPERIMENTAL}

\subsection{Synthesis}

Compounds with an acidic function on the benzene ring $(\mathbf{4 a}, \mathbf{4 b}, \mathbf{4 c})$ were prepared by the method of cyclization used for the synthesis of fenpiclonil. Compounds 7, 9, 11a and 11b were prepared from fenpiclonil (Fig 1).

2.1.1 Synthesis of fenpiclonil derivatives with an acidic function on the benzene ring (Fig 1, 4a, $4 b, 4 c)$

\subsubsection{Preparation of aromatic amines (Fig 1, 1a, 1b, 1c)}

3-Aminobenzoïc acid 1a and ethyl 2-aminobenzoate 1b were obtained from Acros Organics (Noisy-leGrand) and were used for the synthesis of the respective 2-chloronitriles.

Methyl 3-amino-2-chlorobenzoate 1c was prepared from 2-chloro-3-nitrobenzoic acid in two steps. After esterifying the acidic group with thionyl chloride and methanol, the nitro group was reduced with stannous chloride $(5 \mathrm{eq})$ in absolute ethanol. The mixture was stirred at $70^{\circ} \mathrm{C}$ for 30 min, cooled to room temperature, poured on ice and basified $(\mathrm{pH} \approx 7)$ with aqueous sodium carbonate (25\%). The compound was extracted three times with ethyl acetate. After washing the combined organic layers with brine $(15 \mathrm{ml})$ and drying with magnesium sulfate, the solvent was evaporated to provide $1 \mathrm{c}$ as an oil. 
1c. $\mathrm{X}=\mathrm{Cl}$, Y $=\mathrm{COOCH}_{3}$; Yield: $91 \%$; oil; $\mathbf{N M R}{ }^{1} \mathbf{H}\left(\mathrm{CDCl}_{3}\right) \partial(\mathrm{ppm}): 3.84\left(\mathrm{~s}, 3 \mathrm{H}, \mathrm{CH}_{3}\right), 4.41$ (large s, 2H, $\left.\mathrm{NH}_{2}\right), 6.65-7.25\left(\mathrm{~m}, 3 \mathrm{H}, \mathrm{C}_{6} \mathrm{H}_{3}\right)$; $\mathbf{N M R}{ }^{13} \mathbf{C}\left(\mathrm{CDCl}_{3}\right) \partial(\mathrm{ppm}): 51.70\left(\mathrm{CH}_{3}\right), 116.53(\mathrm{C}-\mathrm{Cl})$, 117.96, 119.25 and $126.35(\mathrm{C}-\mathrm{H}), 130.28(\underline{\mathrm{C}}-\mathrm{COO}), 143.98(\mathrm{C}-\mathrm{N}), 166.30(\mathrm{C}=\mathrm{O})$.

\subsubsection{Preparation of 2-chloronitriles (Fig 1, 2a, 2b, 2c) ${ }^{19}$}

To a solution of aromatic amine $\mathbf{1}(10 \mathrm{mmol})$ in acetic acid $(3.5 \mathrm{ml})$, a mixture of hydrochloric acid $(12 \mathrm{M})$ and water $(0.3 \mathrm{ml})$ was added dropwise. After cooling to $0^{\circ} \mathrm{C}$, a solution of sodium nitrite $(0.69 \mathrm{~g} ; 11 \mathrm{mmol})$ in water $(2.1 \mathrm{ml})$ was added dropwise and the mixture was stirred for $2 \mathrm{~h}$ at $0^{\circ} \mathrm{C}$. The resulting solution containing the diazonium salt was then added at $20^{\circ} \mathrm{C}$ to a solution of acrylonitrile $(2.15 \mathrm{~g} ; 40 \mathrm{mmol})$ in acetone $(1 \mathrm{ml})$. After warming to $30^{\circ} \mathrm{C}$, a solution of cuprous chloride $(0.20 \mathrm{~g}, 2$ mmol) in hydrochloric acid (12M, $2.1 \mathrm{ml})$ was added dropwise. The mixture was warmed for $30 \mathrm{~min}$ at $40^{\circ} \mathrm{C}$, poured on ice and extracted with dichloromethane $(3 \times 25 \mathrm{ml})$. The combined organic layers were washed with hydrochloric acid (6M, 2 × $20 \mathrm{ml})$ and water $(2 \times 20 \mathrm{ml})$, dried over magnesium sulfate and evaporated to give 2-chloronitriles $\mathbf{2}$ which were used without further purification.

2a. $\mathrm{X}=\mathrm{H}, \mathrm{Y}=\mathrm{COOH}$; Yield: 79\%; mp 110-116 ${ }^{\circ} \mathrm{C}$ decomp.; $\mathbf{N M R}{ }^{1} \mathbf{H}\left(\mathrm{d}_{6} \mathrm{DMSO}\right) \partial$ (ppm): 3.39 (d, 2H, $\mathrm{CH}_{2}, \mathrm{~J}$ 6.9Hz), 5.30 (t, 1H, CH, J 6.9Hz), 7.15-8.20 (m, 4H, $\left.\mathrm{C}_{6} \mathrm{H}_{4}\right), 11.04$ (s large, 1H, COOH); NMR ${ }^{13} \mathbf{C}\left(\mathrm{d}_{6}\right.$ DMSO) $\partial(\mathrm{ppm}): 41.05\left(\mathrm{CH}_{2}\right), 43.23(\mathrm{C}-\mathrm{Cl}), 117.19(\mathrm{CN}), 128.65,128.97,130.79$ and 134.02 (C-H), 131.42 (ㄸ-COO), $134.61\left(\underline{\mathrm{C}}-\mathrm{CH}_{2}\right), 167.34(\mathrm{C}=\mathrm{O})$.

2b. $\mathrm{X}=\mathrm{COOC}_{2} \mathrm{H}_{5}, \mathrm{Y}=\mathrm{H}$; Yield: $63 \%$; oil; $\mathbf{N M R}{ }^{1} \mathbf{H}\left(\mathrm{CDCl}_{3}\right) \partial(\mathrm{ppm}): 1.39\left(\mathrm{t}, 3 \mathrm{H}, \mathrm{CH}_{3}, \mathrm{~J}\right.$ 7.1Hz), 3.61 (d, 2H, $\left.\mathrm{CH}_{2}, \mathrm{~J} 7.8 \mathrm{~Hz}\right), 4.35$ (q, 2H, $\mathrm{OCH}_{2}, \mathrm{~J}$ 7.1Hz), 4.98 (t, 1H, CH, J 7.8Hz), 7.10-7.70 (m, 3H, H3, H4 and H5), 7.85-8.20 (m, 1H, H6); NMR ${ }^{13} \mathbf{C}\left(\mathrm{CDCl}_{3}\right) \partial(\mathrm{ppm}): 13.96\left(\mathrm{CH}_{3}\right), 41.50$ $\left(\mathrm{CH}_{2}\right), 42.39(\underline{\mathrm{C}}(\mathrm{CN})(\mathrm{Cl})), 61.13\left(\mathrm{OCH}_{2}\right), 116.77(\mathrm{CN}), 129.39(\mathrm{C}-\mathrm{COO}), 128.23,131.18,132.40$ and $132.88(\mathrm{C}-\mathrm{H}), 135.36(\mathrm{C}-\mathrm{Cl}), 166.47(\mathrm{C}=\mathrm{O})$.

2c. $\mathrm{X}=\mathrm{Cl}, \mathrm{Y}=\mathrm{COOCH}_{3}$; Yield: $83 \%$; oil; $\mathbf{N M R}{ }^{1} \mathbf{H}\left(\mathrm{CDCl}_{3}\right) \partial(\mathrm{ppm}): 3.53\left(\mathrm{~d}, 2 \mathrm{H}, \mathrm{CH}_{2}, \mathrm{~J}\right.$ 7.7Hz), 3.93 (s, 3H, $\left.\mathrm{CH}_{3}\right), 4.78$ (t, 1H, CH, J 7.7Hz), 7.20-7.65 (m, 2H, H4 and H5), 7.70-7.90 (m, 1H, 
H6); NMR ${ }^{13} \mathbf{C}\left(\mathrm{CDCl}_{3}\right) \partial(\mathrm{ppm}): 40.66\left(\mathrm{CH}_{2}\right.$ and $\left.\underline{\mathrm{C}}(\mathrm{CN})(\mathrm{Cl})\right), 52.51\left(\mathrm{CH}_{3}\right), 116.23(\mathrm{CN}), 126.85$, 131.06 and $134.94(\mathrm{C}-\mathrm{H}), 131.78,132.82$ and 133.18 (arom. $\mathrm{C}), 165.85(\mathrm{C}=\mathrm{O})$.

\subsubsection{Preparation of cinnamonitriles (Fig 1, $\mathbf{3} \boldsymbol{a}, \mathbf{3} \boldsymbol{b}, \mathbf{3} \boldsymbol{c})^{20}$}

To a solution of 2-chloronitrile $2(14.3 \mathrm{mmol})$ in anhydrous THF $(10 \mathrm{ml})$ was added dropwise at room temperature a solution of 1,8-diazabicyclo[5-4-0]undec-5-ene (DBU) (4.6 g, $30 \mathrm{mmol})$ in anhydrous THF $(34 \mathrm{ml})$. The mixture was stirred overnight then hydrolyzed with water $(15 \mathrm{ml})$. The aqueous phase was acidified to $\mathrm{pH} 2$ using hydrochloric acid (2M) only for 3a and then was extracted with ethyl acetate $(3 \times 20 \mathrm{ml})$. The combined organic layers were washed with hydrochloric acid (2M, $20 \mathrm{ml})$ and water $(20 \mathrm{ml})$, dried over magnesium sulfate and evaporated to provide cinnamonitrile 3. $\mathbf{3 a}$ and $\mathbf{3 b}$ were used without further purification and $\mathbf{3 c}$ was purified by sublimation $\left(110-130^{\circ} \mathrm{C} ; 0.05\right.$ $\mathrm{mm} \mathrm{Hg})$.

3a. $\mathrm{X}=\mathrm{H}, \mathrm{Y}=\mathrm{COOH}$; Yield: 99\%; $\mathrm{mp} 202-214^{\circ} \mathrm{C}$ decomp.; $\mathbf{N M R}{ }^{1} \mathbf{H}\left(\mathrm{d}_{6} \mathrm{DMSO}\right) \partial(\mathrm{ppm})$ : $6.25(\mathrm{~d}, 1 \mathrm{H},=\mathrm{CHCN}, \mathrm{J} 16.7 \mathrm{~Hz}), 7.20-8.30\left(\mathrm{~m}, 5 \mathrm{H}, \mathrm{C}_{6} \mathrm{H}_{4}\right.$ and $\left.\mathrm{CH}=\right), 10.71(\mathrm{~s}$ large, $1 \mathrm{H}, \mathrm{COOH}) ; \mathbf{N M R}$ ${ }^{13} \mathbf{C}\left(\mathrm{d}_{6}\right.$ DMSO) $\partial(\mathrm{ppm}): 97.62(=\underline{\mathrm{CHCN}}) ; 117.85(\mathrm{CN}), 128.35,128.86,131.03$ and 131.51 (arom. $\mathrm{CH}) ; 131.78$ and 133.63 (arom. C), $149.26(\mathrm{CH}=), 166.81(\mathrm{C}=\mathrm{O})$.

3b. $\mathrm{X}=\mathrm{COOC}_{2} \mathrm{H}_{5}, \mathrm{Y}=\mathrm{H}$; Yield: $96 \%$; oil; $\mathbf{N M R}{ }^{1} \mathbf{H}\left(\mathrm{CDCl}_{3}\right) \partial(\mathrm{ppm}): 1.40$ (t, 3H, $\left.\mathrm{CH}_{3}, \mathrm{~J} 7.0 \mathrm{~Hz}\right)$, 4.37 (q, 2H, $\left.\mathrm{CH}_{2}, \mathrm{~J} 7.0 \mathrm{~Hz}\right), 5.78(\mathrm{~d}, 1 \mathrm{H},=\mathrm{CHCN}, \mathrm{J} 16.6 \mathrm{~Hz}), 7.15-8.10\left(\mathrm{~m}, 4 \mathrm{H}, \mathrm{C}_{6} \mathrm{H}_{4}\right), 8.28(\mathrm{~d}, 1 \mathrm{H}$, $\mathrm{CH}=, \mathrm{J} 16.6 \mathrm{~Hz}) ; \mathbf{N M R}{ }^{13} \mathbf{C}\left(\mathrm{CDCl}_{3}\right) \partial(\mathrm{ppm}): 13.78\left(\mathrm{CH}_{3}\right), 61.13\left(\mathrm{CH}_{2}\right), 98.45(=\underline{\mathrm{CHCN}}), 117.43$ (CN), 129.00 (--COO), 126.82, 129.90, 130.55 and 132.19 (arom. $\mathrm{CH}), 134.79(\underline{\mathrm{C}}-\mathrm{CH}=), 149.53$ $(\mathrm{CH}=), 165.76(\mathrm{C}=\mathrm{O})$.

3c. $\mathrm{X}=\mathrm{Cl}, \mathrm{Y}=\mathrm{COOCH}_{3}$; Yield: $68 \%$; mp 66-76 ${ }^{\circ} \mathrm{C}$; $\mathbf{N M R}{ }^{1} \mathbf{H}\left(\mathrm{CDCl}_{3}\right) \partial(\mathrm{ppm}): 3.94(\mathrm{~s}, 3 \mathrm{H}$, $\left.\mathrm{CH}_{3}\right), 5.96(\mathrm{~d}, 1 \mathrm{H},=\mathrm{CHCN}, \mathrm{J} 16,7 \mathrm{~Hz}), 7.15-8.15\left(\mathrm{~m}, 4 \mathrm{H}, \mathrm{C}_{6} \mathrm{H}_{3}\right.$ and $\left.\mathrm{CH}=\right) ; \mathbf{N M R}{ }^{13} \mathbf{C}\left(\mathrm{CDCl}_{3}\right) \partial$ (ppm): $52.42\left(\mathrm{CH}_{3}\right), 100.18(=\underline{\mathrm{CHCN}}), 117.07(\mathrm{CN}), 126.73,129.36$, and 132.52 (arom. $\left.\mathrm{CH}\right), 132.02$, 132.25 and 133.18 (arom. C), $145.80(\mathrm{CH}=), 165.46(\mathrm{C}=\mathrm{O})$. 


\subsubsection{Synthesis of phenylpyrroles (Fig $1,4 \boldsymbol{a}, \mathbf{4 b}, \mathbf{4 c})^{21}$}

To a mixture of 3 (6 mmol), p-(tolylsulfonyl)methyl isocyanide (TosMIC, $1.17 \mathrm{~g}, 6 \mathrm{mmol}$ ), anhydrous dimethylsulfoxide $(5.5 \mathrm{ml})$ and anhydrous diethyl ether $(10 \mathrm{ml})$ was added dropwise a suspension of $\mathrm{NaH}(0.34 \mathrm{~g}, 14.4 \mathrm{mmol}$ for $\mathbf{4 a}, 0.50 \mathrm{~g}, 21 \mathrm{mmol}$ for $\mathbf{4 b}$ and $\mathbf{4 c})$ in anhydrous diethyl ether $(25 \mathrm{ml}$ for $4 \mathbf{a}, 38 \mathrm{ml}$ for $\mathbf{4 b}$ and $\mathbf{4 c})$ at $20^{\circ} \mathrm{C}$. The mixture was stirred at $20^{\circ} \mathrm{C}$ for $1 \mathrm{~h}(\mathbf{4 a})$ or $3 \mathrm{~h}$ (4b and $4 \mathbf{c})$ and then warmed at $34^{\circ} \mathrm{C}$ for $2 \mathrm{~h}(\mathbf{4 b}$ and $\mathbf{4 c})$. After cooling to room temperature, diethyl ether $(20 \mathrm{ml})$ and water $(20 \mathrm{ml})$ were added. The aqueous layer was acidified using hydrochloric acid $(2 \mathrm{M}, \mathrm{pH} 2.0)$ and then extracted with ethyl acetate $(3 \times 15 \mathrm{ml})$. The ethyl acetate layers were combined, washed with water $(6 \times 20 \mathrm{ml})$, dried over anhydrous magnesium sulfate and evaporated to give phenylpyrroles 4 .

4a. $\mathrm{X}=\mathrm{H}, \mathrm{Y}=\mathrm{COOH}$; Yield: $65 \%$; mp $236-246^{\circ} \mathrm{C}$ decomp.; $\mathbf{N M R}{ }^{1} \mathbf{H}\left(\mathrm{d}_{6} \mathrm{DMSO}\right) \partial$ (ppm): 6.90-8.90 (m, 7H, H2, H5, $\mathrm{C}_{6} \mathrm{H}_{4}$ and $\mathrm{NH}$ or $\left.\mathrm{COOH}\right), 11.99$ (s large, $1 \mathrm{H}, \mathrm{NH}$ or $\left.\mathrm{COOH}\right) ; \mathbf{N M R}{ }^{13} \mathbf{C}\left(\mathrm{d}_{6}\right.$ DMSO) $\partial$ (ppm): $89.44(\underline{\mathrm{C}}-\mathrm{CN}), 117.16(\mathrm{CN}), 124.26\left(\underline{\mathrm{C}}-\mathrm{C}_{6} \mathrm{H}_{4}\right), 118.14,126.65,127.42,128.23$, 129.03 and $130.14(\mathrm{CH}), 131.48$ and 133.63 (arom. $\mathrm{C}), 167.22(\mathrm{C}=\mathrm{O})$.

4b. $\mathrm{X}=\mathrm{COOH}, \mathrm{Y}=\mathrm{H}$; Yield: $63 \%$; mp 77-89 ${ }^{\circ} \mathrm{C}$ decomp.; $\mathbf{N M R}{ }^{1} \mathbf{H}\left(\mathrm{d}_{6} \mathrm{DMSO}\right) \partial(\mathrm{ppm}): 6.70$ $8.50\left(\mathrm{~m}, 7 \mathrm{H}, \mathrm{H} 2, \mathrm{H} 5, \mathrm{C}_{6} \mathrm{H}_{4}\right.$ and $\mathrm{NH}$ or $\left.\mathrm{COOH}\right), 11.76$ (s large, $1 \mathrm{H}, \mathrm{NH}$ or $\left.\mathrm{COOH}\right) ; \mathbf{N M R}{ }^{13} \mathbf{C}\left(\mathrm{d}_{6}\right.$ DMSO) $\partial$ (ppm): 92.22 (ㅁ-CN), $116.89(\mathrm{CN}), 125.30\left(\underline{\mathrm{C}}-\mathrm{C}_{6} \mathrm{H}_{4}\right), 118.29,127.01,127.18,129.42$, 130.91 and $131.09(\mathrm{CH}), 132.29$ and 132.67 (arom. $\mathrm{C}), 169.13(\mathrm{C}=\mathrm{O})$.

4c. $\mathrm{X}=\mathrm{Cl}$, Y $=\mathrm{COOH}$; Yield: $52 \%$; mp $158-170^{\circ} \mathrm{C}$ decomp.; $\mathbf{N M R}{ }^{1} \mathbf{H}\left(\mathrm{d}_{6} \mathrm{DMSO}\right) \partial$ (ppm): 6.80-8.05 (m, 5H, H2, H5 and $\left.\mathrm{C}_{6} \mathrm{H}_{3}\right), 10.10$ and 11.98 (2s large, $2 \mathrm{H}, \mathrm{NH}$ and $\left.\mathrm{COOH}\right) ; \mathbf{N M R}{ }^{13} \mathbf{C}\left(\mathrm{d}_{6}\right.$ DMSO) $\partial$ (ppm): 92.55 (ㅁ-CN), $116.65(\mathrm{CN}), 122.53\left(\underline{\mathrm{C}}-\mathrm{C}_{6} \mathrm{H}_{3}\right), 120.05,126.92,127.36,128.86$ and $133.60(\mathrm{CH}), 129.99,133.60$ and 134.11 (arom. C), $167.58(\mathrm{C}=\mathrm{O})$.

2.1.2 Synthesis of a fenpiclonil derivative with an acidic function on the pyrrole ring $($ Fig 1,7$)$

2.1.2.1 3-Cyano-4-(2,3-dichlorophenyl)-N-phenylsulfonylpyrrole (Fig 1, 5) 
A solution of n-butyllithium in hexane $(6.6 \mathrm{ml}$ of $1.6 \mathrm{M}$ solution, $10.05 \mathrm{mmol})$ was added dropwise at $0^{\circ} \mathrm{C}$ to a solution of fenpiclonil $(2.37 \mathrm{~g}, 10 \mathrm{mmol})$ in anhydrous degassed THF $(30 \mathrm{ml})$. The mixture was stirred for $3 \mathrm{~h}$ at $0^{\circ} \mathrm{C}$, then benzenesulfonyl chloride was added at the same temperature $(1.94 \mathrm{~g}, 11 \mathrm{mmol})$. The mixture was stirred for an additional $2 \mathrm{~h}$ at $0^{\circ} \mathrm{C}$ and overnight at room temperature, then poured into aqueous sodium bicarbonate $(5 \%, 50 \mathrm{ml})$. The aqueous phase was extracted with dichloromethane $(3 \times 25 \mathrm{ml})$ and the combined organic layers were washed with aqueous sodium bicarbonate $(5 \%, 40 \mathrm{ml})$, water $(40 \mathrm{ml})$ and brine $(40 \mathrm{ml})$. After drying and removing the solvent, the crude product was chromatographed on a column of silica gel using dichloromethane as eluant to give $\mathbf{5}$ as an oil which slowly crystallized on standing.

5. Yield: $85 \%$; mp $80^{\circ} \mathrm{C}$; NMR ${ }^{1} \mathbf{H}\left(\mathrm{d}_{6}\right.$ acetone) $\partial(\mathrm{ppm}): 7.30-8.30\left(\mathrm{~m}, 10 \mathrm{H}, \mathrm{H} 2, \mathrm{H} 5, \mathrm{C}_{6} \mathrm{H}_{3}\right.$ and $\left.\mathrm{C}_{6} \mathrm{H}_{5}\right) ; \mathbf{N M R}{ }^{13} \mathbf{C}\left(\mathrm{d}_{6}\right.$ acetone $) \partial(\mathrm{ppm}): 100.83(\underline{\mathrm{C}}-\mathrm{CN}), 114.43(\mathrm{CN}), 127.68\left(\underline{\mathrm{C}}-\mathrm{C}_{6} \mathrm{H}_{3}\right), 122.31$, $128.81,129.14,129.77,131.35,131.98$ and $136.63(\mathrm{CH}), 132.54,133.41,134.51$ and 138.57 (arom. C).

\subsubsection{3-Cyano-4-(2,3-dichlorophenyl)-2-methoxycarbonyl-N-phenylsulfonyl pyrrole (Fig 1, 6) ${ }^{22}$}

A solution of n-butyllithium in hexane $(1.8 \mathrm{ml}$ of $1.6 \mathrm{M}$ solution, $2.85 \mathrm{mmol})$ was added dropwise to diisopropylamine $(0.3 \mathrm{~g}, 3 \mathrm{mmol})$ dissoved in THF $(7 \mathrm{ml})$. The mixture was stirred at $0^{\circ} \mathrm{C}$ for 15 min then cooled to $-80^{\circ} \mathrm{C}$. A solution of $5(1 \mathrm{~g}, 2.65 \mathrm{mmol})$ in degassed THF $(7 \mathrm{ml})$ was added dropwise. After stirring at $-80^{\circ} \mathrm{C}$ for $1 \mathrm{~h}$, methyl chloroformate $(1.5 \mathrm{~g}, 16 \mathrm{mmol})$ was added dropwise. The mixture was stirred at $-80^{\circ} \mathrm{C}$ for $5 \mathrm{~h}$ and at room temperature overnight. Saturated aqueous ammonium chloride $(15 \mathrm{ml})$ and dichloromethane $(15 \mathrm{ml})$ were then successively added. The aqueous phase was extracted with dichloromethane $(2 \times 15 \mathrm{ml})$ and the combined organic layers were washed with water $(15 \mathrm{ml})$ and brine $(15 \mathrm{ml})$. After removing solvent and then volatile impurities under vacuum $\left(140^{\circ} \mathrm{C}, 0.01 \mathrm{~mm} \mathrm{Hg}\right), 6$ was obtained as an oil which slowly crystallized on standing.

6. Yield: $87 \%$; mp $115-116^{\circ} \mathrm{C}$; NMR ${ }^{1} \mathbf{H}\left(\mathrm{CDCl}_{3}\right) \partial(\mathrm{ppm}): 3.88\left(\mathrm{~s}, 3 \mathrm{H}, \mathrm{CH}_{3}\right), 7.15-8.20(\mathrm{~m}, 9 \mathrm{H}$, $\mathrm{H} 5, \mathrm{C}_{6} \mathrm{H}_{3}$ and $\left.\mathrm{C}_{6} \mathrm{H}_{5}\right) ; \mathbf{N M R}{ }^{13} \mathbf{C}\left(\mathrm{CDCl}_{3}\right) \partial(\mathrm{ppm}): 52.62\left(\mathrm{CH}_{3}\right), 105.19(\underline{\mathrm{C}}-\mathrm{CN}), 112.25(\mathrm{CN}), 124.88$ 
$\left(\underline{\mathrm{C}}-\mathrm{C}_{6} \mathrm{H}_{3}\right), 126.73,127.36,128.52,129.00,129.48,130.79$ and $134.82(\mathrm{CH}), 131.60,133.81$ and 136.91 (arom. C), $156.99(\mathrm{C}=\mathrm{O})$.

\subsubsection{2-Carboxy-3-cyano-4-(2,3-dichlorophenyl)pyrrole (Fig 1, 7) ${ }^{22}$}

A mixture of $6(1.3 \mathrm{~g}, 3 \mathrm{mmol})$, THF $(100 \mathrm{ml})$ and methanol $(300 \mathrm{ml})$ was treated with aqueous sodium hydroxide $(8 \mathrm{M}, 120 \mathrm{ml})$ and refluxed for $48 \mathrm{~h}$. After cooling to room temperature, solvents were removed and the residue was taken up in water $(400 \mathrm{ml})$. The aqueous layer was acidified using hydrochloric acid (12M) and then extracted with ethyl acetate $(3 \times 50 \mathrm{ml})$. The combined organic layers were washed with water $(2 \times 10 \mathrm{ml})$, dried over anhydrous magnesium sulfate and evaporated to give 7 as a solid which was purified by washing with dichloromethane $(5 \mathrm{ml})$.

7. Yield: 70\%; mp 247-249 ${ }^{\circ} \mathrm{C}$ decomp.; NMR ${ }^{1} \mathbf{H}\left(\mathrm{d}_{6} \mathrm{DMSO}\right) \partial(\mathrm{ppm}): 7.10-7.90$ (m, H5 and $\left.\mathrm{C}_{6} \mathrm{H}_{3}\right), 13.06$ and 13.40 (s and large s, 2H, NH and $\left.\mathrm{COOH}\right)$; NMR ${ }^{13} \mathbf{C}\left(\mathrm{d}_{6} \mathrm{DMSO}\right) \partial(\mathrm{ppm})$ : 96.96 (C$\mathrm{CN}), 114.74(\mathrm{CN}), 125.60\left(\underline{\mathrm{C}}-\mathrm{C}_{6} \mathrm{H}_{3}\right), 123.60,128.11,130.17$ and $130.50(\mathrm{CH}), 128.41,130.86,132.59$ and 133.48 (arom. C), $159.82(\mathrm{C}=\mathrm{O})$.

\subsubsection{Synthesis of N-substituted fenpiclonil derivatives (Fig 1, 9 and 11)}

\subsubsection{3-Cyano-4-(2,3-dichlorophenyl)-N-(1-methoxycarbonylmethyl)pyrrole $\boldsymbol{8}$}

Fenpiclonil (2.37 g, $10 \mathrm{mmol})$ was lithiated with n-butyllithium as described in $\S 2.1 .2 .1$. A solution of methyl bromoacetate $(2.29 \mathrm{~g}, 15 \mathrm{mmol})$ in degassed THF $(20 \mathrm{ml})$ was added dropwise and the mixture was stirred for $3 \mathrm{~h}$ at $0^{\circ} \mathrm{C}$ and overnight at room temperature. After cooling to $0^{\circ} \mathrm{C}$, cold water $(50 \mathrm{ml})$ was added dropwise. The aqueous phase was extracted with dichloromethane $(3 \times 25$ $\mathrm{ml})$. The combined dichloromethane layers were washed with water $(20 \mathrm{ml})$, dried over anhydrous magnesium sulfate and evaporated to provide $\mathbf{8}$ as yellowish crystals.

8. Yield: $71 \%$; mp $130^{\circ} \mathrm{C}$; NMR ${ }^{1} \mathbf{H}\left(\mathrm{CDCl}_{3}\right) \partial$ (ppm): $3.76\left(\mathrm{~s}, 3 \mathrm{H}, \mathrm{CH}_{3}\right), 4.68\left(\mathrm{~s}, 2 \mathrm{H}, \mathrm{CH}_{2}\right), 6.93$ (d, 1H, H5, J 2.0Hz), 7.15-7.50 (m, 4H, H2 and $\left.\mathrm{C}_{6} \mathrm{H}_{3}\right) ; \mathbf{N M R}{ }^{13} \mathbf{C}\left(\mathrm{CDCl}_{3}\right) \partial(\mathrm{ppm}): 50.77\left(\mathrm{CH}_{2}\right)$, $52.68\left(\mathrm{CH}_{3}\right), 94.36(\underline{\mathrm{C}}-\mathrm{CN}), 115.34(\mathrm{CN}), 123.87\left(\underline{\mathrm{C}}-\mathrm{C}_{6} \mathrm{H}_{3}\right), 123.24,127.12$ and $129.48(\mathrm{CH}), 131.12$, 133.24 and 133.57 (arom. C), $167.43(\mathrm{C}=\mathrm{O})$. 


\subsubsection{N-Carboxymethyl-3-cyano-4-(2,3-dichlorophenyl)pyrrole $9^{23,24}$}

A mixture of $8(3.09 \mathrm{~g}, 10 \mathrm{mmol})$, lithium iodide $(9.3 \mathrm{~g}, 57 \mathrm{mmol})$ and DMF (300 $\mathrm{ml})$ was refluxed for $18 \mathrm{~h}$. The mixture was cooled to room temperature, diluted with water $(300 \mathrm{ml})$, acidified using hydrochloric acid (2M) and then extracted with dichloromethane $(3 \times 50 \mathrm{ml})$. The combined organic layers were washed with water $(3 \times 30 \mathrm{ml})$, dried over anhydrous magnesium sulfate and evaporated to provide 9 as a brown powder.

9. Yield: $61 \%$; mp $192{ }^{\circ} \mathrm{C}$; $\mathbf{N M R}^{1} \mathbf{H}\left(\mathrm{d}_{6} \mathrm{DMSO}\right) \partial(\mathrm{ppm}): 4.88\left(\mathrm{~s}, 2 \mathrm{H}, \mathrm{CH}_{2}\right), 7.18(\mathrm{~d}, 1 \mathrm{H}, \mathrm{H} 5, \mathrm{~J}$ 2.0Hz), 7.25-7.85 (m, 4H, H2 and $\left.\mathrm{C}_{6} \mathrm{H}_{3}\right), 10.45$ (large s, $\left.1 \mathrm{H}, \mathrm{OH}\right) ; \mathbf{N M R}{ }^{13} \mathbf{C}\left(\mathrm{d}_{6}\right.$ DMSO) $\partial$ (ppm): $50.60\left(\mathrm{CH}_{2}\right), 92.40(\underline{\mathrm{C}}-\mathrm{CN}), 115.82(\mathrm{CN}), 122.23\left(\underline{\mathrm{C}}-\mathrm{C}_{6} \mathrm{H}_{3}\right), 124.05,127.81,129.45,129.90$ and $130.85(\mathrm{CH}), 130.47,132.76$ and 133.96 (arom. $\mathrm{C}), 169.40(\mathrm{C}=\mathrm{O})$.

\subsubsection{3-Cyano-4-(2,3-dichlorophenyl)-N-(2-methoxycarbonylethyl)pyrrole 10a and 3-Cyano-4-} (2,3-dichlorophenyl)-N-(3-methoxycarbonylpropyl)pyrrole $\mathbf{1 0 b}^{25}$

A solution of sodium methoxide in methanol ( $2 \mathrm{ml}$, sol. 30\%) was added dropwise to a solution of fenpiclonil (2.37 g, $10 \mathrm{mmol})$ in anhydrous DMF. The mixture was stirred at room temperature for $3 \mathrm{~h}$ and treated dropwise with a solution of methyl 3-bromopropionate (for 10a) or methyl 4bromobutyrate (for 10b) $(10 \mathrm{mmol})$ and sodium iodide $(0.40 \mathrm{~g}, 2.7 \mathrm{mmol})$ in DMF $(16 \mathrm{ml})$. The mixture was warmed at $100-105^{\circ} \mathrm{C}$ for $24 \mathrm{~h}(\mathbf{1 0 a})$ or at $120-125^{\circ} \mathrm{C}$ for $10 \mathrm{~h}(\mathbf{1 0 b})$. After cooling and addition of water $(40 \mathrm{ml})$, the aqueous layer was extracted with dichloromethane $(3 \mathrm{x} 25 \mathrm{ml})$ and the combined organic layers were washed with water $(10 \mathrm{ml})$, dried over anhydrous magnesium sulfate and evaporated. The crude products were chromatographed on a column of silica gel using chloroform/methyl acetate ( $9 / 1$ by volume) as eluant.

10a. Yield: $60 \%$; mp $64^{\circ} \mathrm{C}$; $\mathbf{N M R}^{1} \mathbf{H}\left(\mathrm{CDCl}_{3}\right) \partial$ (ppm): 2.80 (t, $2 \mathrm{H}, \mathrm{CH}_{2}, \mathrm{~J}$ 6.4Hz); 3.67 (s, 3H, $\left.\mathrm{OCH}_{3}\right), 4.24\left(\mathrm{t}, 2 \mathrm{H}, \mathrm{NCH}_{2}, \mathrm{~J}\right.$ 6.4Hz), $6.95\left(\mathrm{~d}, 1 \mathrm{H}, \mathrm{H} 5, \mathrm{~J}\right.$ 2.3Hz), 7.05-7.50 (m, 4H, H2 and $\left.\mathrm{C}_{6} \mathrm{H}_{3}\right)$; NMR ${ }^{13} \mathbf{C}\left(\mathrm{CDCl}_{3}\right) \partial(\mathrm{ppm}): 35.17\left(\mathrm{CH}_{2}\right), 45.37\left(\mathrm{NCH}_{2}\right), 51.73\left(\mathrm{OCH}_{3}\right), 93.35(\underline{\mathrm{C}}-\mathrm{CN}), 115.52(\mathrm{CN})$, 
$123.51\left(\underline{\mathrm{C}}-\mathrm{C}_{6} \mathrm{H}_{3}\right), 122.08,126.97,128.32,129.18$ and $129.30(\mathrm{CH}), 130.85$ and 133.33 (arom. C), $170.47(\mathrm{C}=\mathrm{O})$.

10b. Yield: 58\%; oil; NMR ${ }^{1} \mathbf{H}\left(\mathrm{CDCl}_{3}\right) \partial$ (ppm): 1.85-2.50 (m, 4H, $\left.\mathrm{CH}_{2}\right), 3.67\left(\mathrm{~s}, 3 \mathrm{H}, \mathrm{OCH}_{3}\right)$, $4.01\left(\mathrm{t}, 2 \mathrm{H}, \mathrm{NCH}_{2}, \mathrm{~J} 6.6 \mathrm{~Hz}\right), 6.92(\mathrm{~d}, 1 \mathrm{H}, \mathrm{H} 5, \mathrm{~J} 2.2 \mathrm{~Hz}), 7.05-7.55\left(\mathrm{~m}, 4 \mathrm{H}, \mathrm{H} 2\right.$ and $\left.\mathrm{C}_{6} \mathrm{H}_{3}\right) ; \mathbf{N M R}{ }^{{ }^{13} \mathbf{C}}$ $\left(\mathrm{CDCl}_{3}\right) \partial(\mathrm{ppm}): 25.89\left(\mathrm{CH}_{2}\right), 30.01\left(\mathrm{CH}_{2} \mathrm{CO}\right), 49.07\left(\mathrm{NCH}_{2}\right), 51.43\left(\mathrm{OCH}_{3}\right), 93.29(\underline{\mathrm{C}}-\mathrm{CN}), 115.58$ $(\mathrm{CN}), 123.57\left(\underline{\mathrm{C}}-\mathrm{C}_{6} \mathrm{H}_{3}\right), 122.02,127.00,128.05,129.21$ and $129.33(\mathrm{CH}), 130.94,133.39$ and 133.48 (arom. C), $172.29(\mathrm{C}=\mathrm{O})$.

2.1.3.4 N-(2-Carboxyethyl)-3-cyano-4-(2,3-dichlorophenyl)pyrrole 11 a and N-(3-carboxypropyl)-3-cyano-4-(2,3-dichlorophenyl)pyrrole $\mathbf{1 1 b}^{26}$

Aqueous sodium hydroxide $(1.25 \mathrm{M}, 21 \mathrm{ml})$ was added to a solution of ester $\mathbf{1 0}(10 \mathrm{mmol})$ in $95 \%$ ethanol $(18 \mathrm{ml})$. The mixture was stirred at room temperature for $1 \mathrm{~h}$ and then warmed at $60^{\circ} \mathrm{C}$ for an additional hour. After cooling and diluting with water $(28 \mathrm{ml})$, the aqueous layer was extracted with dichloromethane (3 x $40 \mathrm{ml})$ and acidified using hydrochloric acid (2M, $\mathrm{pH} 1-2)$. The acidic layer was extracted with dichloromethane ( $3 \times 40 \mathrm{ml})$, dried over anhydrous magnesium sulfate and evaporated to provide 11.

11a. Yield: $98 \%$; mp $129-133^{\circ} \mathrm{C}$; $\mathbf{N M R}{ }^{1} \mathbf{H}\left(\mathrm{CDCl}_{3}+\mathrm{d}_{6} \mathrm{DMSO}\right) \partial(\mathrm{ppm}): 2.80\left(\mathrm{t}, 2 \mathrm{H}, \mathrm{CH}_{2}, \mathrm{~J}\right.$ 6.5Hz), $4.26\left(\mathrm{t}, 2 \mathrm{H}, \mathrm{NCH}_{2}, \mathrm{~J}\right.$ 6.5Hz), $7.06(\mathrm{~d}, 1 \mathrm{H}, \mathrm{H} 5, \mathrm{~J} 2.3 \mathrm{~Hz}), 7.15-7.70\left(\mathrm{~m}, 4 \mathrm{H}, \mathrm{H} 2\right.$ and $\left.\mathrm{C}_{6} \mathrm{H}_{3}\right), 7,80$ (large s, $1 \mathrm{H}, \mathrm{OH}) ; \mathbf{N M R}{ }^{13} \mathrm{C}\left(\mathrm{CDCl}_{3}+\mathrm{d}_{6} \mathrm{DMSO}\right) \partial(\mathrm{ppm}): 35.17\left(\mathrm{CH}_{2}\right) ; 45.41\left(\mathrm{NCH}_{2}\right), 92,49(\underline{\mathrm{C}}-$ $\mathrm{CN}), 115.43(\mathrm{CN}), 122.83\left(\underline{\mathrm{C}}-\mathrm{C}_{6} \mathrm{H}_{3}\right), 122.17,127.01,128.68,128.97$ and $129.33(\mathrm{CH}), 130.56,132.82$ and 133.60 (arom. C), $171.64(\mathrm{C}=\mathrm{O})$.

11b. Yield: $91 \%$; mp $121{ }^{\circ} \mathrm{C}$; NMR ${ }^{1} \mathbf{H}\left(\mathrm{CDCl}_{3}+\mathrm{d}_{6} \mathrm{DMSO}\right) \partial(\mathrm{ppm}): 1.70-2.45\left(\mathrm{~m}, 4 \mathrm{H}, \mathrm{CH}_{2}\right)$, 4.05 (t, 2H, $\mathrm{NCH}_{2}, \mathrm{~J}$ 6.6Hz), 4.75 (large s, 1H, OH), 7.18 (d, 1H, H5, J 2.0Hz), 7.30-7.90 (m, 4H, H2 and $\left.\mathrm{C}_{6} \mathrm{H}_{3}\right)$; NMR ${ }^{13} \mathrm{C}\left(\mathrm{CDCl}_{3}+\mathrm{d}_{6} \mathrm{DMSO}\right) \partial(\mathrm{ppm}): 25.86\left(\mathrm{CH}_{2}\right), 30.34\left(\mathrm{CH}_{2} \mathrm{CO}\right), 48.81\left(\mathrm{NCH}_{2}\right)$, 
$92.01(\underline{\mathrm{C}}-\mathrm{CN}), 115.79(\mathrm{CN}), 122.56\left(\underline{\mathrm{C}}-\mathrm{C}_{6} \mathrm{H}_{3}\right), 122.56,127.72,129.27,129.36$ and $129.90(\mathrm{CH})$, 130.35, 132.49 and 133.96 (arom. C), $173.43(\mathrm{C}=\mathrm{O})$.

\subsection{In vitro fungicidal activity on Eutypa lata}

\subsubsection{Fungal-growth conditions}

The strain of Eutypa lata Pers. Fr. Tul. \& C. Tul. used in these experiments was isolated from a vine stock showing symptoms of eutypiosis. The strain was grown on a sterile culture medium solidified with agar $\left(20 \mathrm{~g} \mathrm{litre}^{-1}\right)$, containing malt extract $\left(15 \mathrm{~g}\right.$ litre $\left.{ }^{-1}\right)$ and chloramphenicol $(0.25 \mathrm{~g}$ litre $\left.^{-1}\right)$. This pathogenic fungus destroys wood, cambium and phloem.

\subsubsection{Mycelium-growth assays}

The effects of phenylpyrroles on mycelial growth were measured on cultures made in wells (35 or $55 \mathrm{~mm}$ diameter), containing the solid medium (as above). The media were autoclaved under $500 \mathrm{hPa}$ for $15 \mathrm{~min}$. Compounds were added during cooling at $50-55^{\circ} \mathrm{C}$ at the desired concentration from a 100 $\mathrm{mM}$ aqueous stock solution. The inoculum consisted of a $3 \mathrm{~mm}$ diameter mycelial disk taken from a solid culture. The experiments were carried out in the dark at $20^{\circ} \mathrm{C}$. The diameter of the mycelium was measured daily in six identical wells for 7 and 21 days.

\subsection{Tests of systemicity}

\subsubsection{Plant material}

Castor bean seeds (Ricinus communis cv Sanguineus), obtained from Ball-Ducrettet (Margencel, France), were placed in humid cotton-wool for $24 \mathrm{~h}$ at $27^{\circ} \mathrm{C} \pm 1^{\circ} \mathrm{C}$ prior to sowing in wet vermiculite. Seedlings were grown in a humid atmosphere $(80 \% \pm 5 \%)$ at $27^{\circ} \mathrm{C} \pm 1{ }^{\circ} \mathrm{C}$ in $\operatorname{dim}$ light $(14 \mathrm{~h}$ photoperiod) and used 6 days after sowing. 


\subsubsection{Electrophysiological measurements}

The hook region (i.e. the upper part of the hypocotyl) was severed from the base of the seedling and then fixed to the bottom of a Petri dish with inert adhesive paste (Terostat). Tissues were preincubated in a standard medium containing calcium chloride $(0.5 \mathrm{mM})$, magnesium chloride $(0.25$ $\mathrm{mM}$ ), ethanol (2\%) and 2-[N-morpholino] ethanesulfonic acid (MES) (20 mM) as buffer (pH 5.0). After $1 \mathrm{~h}$ preincubation, the tissues were incubated in the same solution without (control) or with compound $9(0.25 \mathrm{mM})$. The reference electrode was bathed in this medium, and a glass microelectrode was inserted into a cell of the outer part of the cortical parenchyma. Transmembrane potential difference (PD) measurements were repeated over a 400 min period. They were made in a Faraday cage, using the equipment previously described. ${ }^{27}$ In brief, the glass microelectrode (tip diameter $<1 \mu \mathrm{m}$, tip resistance 15-20 M $\Omega$ ) and the reference microelectrode (diameter $1 \mathrm{~mm}$, filled with $3 \mathrm{M} \mathrm{KCl}$ in $1 \%$ agar) were connected to an electrometer-amplifier (model M707, WP instruments, New-Haven, CT). The output signal of the amplifier was monitored with an oscilloscope (DM 64, Telequipment, Tektronix UK, London, UK) and a chart recorder (Kipp and Zonen, Delft, The Netherlands).

\subsubsection{Sap collection and analysis 28,29}

The endosperm of seedlings was carefully removed without bending or crushing the cotyledons. These latter organs were preincubated for $30 \mathrm{~min}$ in a buffer solution containing magnesium chloride $(0.25 \mathrm{mM})$ and calcium chloride $(0.5 \mathrm{mM})$, then incubated in the same medium supplemented with compound 9 at $250 \mu \mathrm{M}$ concentration. Thirty minutes or two hours later according to the experiments, the hypocotyl was severed in the hook region for phloem exudation. The phloem sap was collected from the upper part of the hypocotyl maintained in the incubation solution and was stored in ice until analysis. To reduce evaporation, the sap was collected in a Plexiglas microcabinet laid out with wet filter paper. The buffers used were MES $20 \mathrm{mM}$ (pH 5.0-6.5) and HEPES $20 \mathrm{mM}$ (pH 4.6, 7.0 and 8.2). Buffers containing citrate could not be used at acidic $\mathrm{pH}$ due to their chelating effect toward cations and especially $\mathrm{Ca}^{++}$. Due to the weak buffer properties of HEPES around $\mathrm{pKa}_{1}$ (3.55), the 
stated $\mathrm{pH}$ value (4.6) was the mean of the initial $\mathrm{pH}$ of the incubation medium $(\mathrm{pH} 4.3)$ and that measured at the end of the experiment (4.9 or 5.0). The phloem sap was analyzed by HPLC after dilution with pure water. We employed reverse-phase chromatography using a Discovery C16 RPamide column (length $250 \mathrm{~mm}$, internal diameter 4,6 mm) (Supelco, Bellefonte, PA), eluting with water containing $0.1 \%$ trifluoroacetic acid and acetonitrile $(1: 1)$ (flow $0.8 \mathrm{ml} \mathrm{min}^{-1}$ ) connected to a photodiode array detector $(218 \mathrm{~nm})$.

\section{RESULTS AND DISCUSSION}

\subsection{Screening of the active and non active derivatives}

Measuring the short-term effect of fenpiclonil and the various acidic derivatives at $100 \mu \mathrm{M}$ concentration on the mycelial growth of Eutypa lata (Fig 2), compounds $\mathbf{4 a}, \mathbf{4 b}$ and $\mathbf{4} \mathbf{c}$ had no biological activity but the other derivatives inhibited the growth of the fungus by approximately $60 \%$. After a three-week culture, compounds 11a, 11b and especially 9 exhibited the greatest efficacy, despite being less active than fenpiclonil under our experimental conditions. Compound 9 at $50 \mu \mathrm{M}$ concentration not only limited fungal growth (Fig 3) but also destroyed the oldest part of the mycelial colony around the inoculum disk. These effects became increasingly tenuous at lower doses. At 10 $\mu \mathrm{M}$, biological activity was no longer noted, whereas at the same concentration, fenpiclonil exhibited approximately the same effect as compound 9 at $50 \mu \mathrm{M}$.

The biological effect of the various xenobiotics must be influenced in part by their capacity to be taken up by the fungus. Fenpiclonil $\left(\log \mathrm{K}_{\mathrm{ow}}=3.9\right)$ is rapidly accumulated to high levels in mycelial suspensions of Fusarium sulphureum, particularly into mycelial lipids. ${ }^{30}$ On the other hand, excepting compound 7, our acidic derivatives are lipophilic only in their undissociated form (Fig 4). As a consequence, their uptake depends on the $\mathrm{pH}$ of the external medium. The $\mathrm{pH}$ of the culture medium of Eutypa lata ranges from 5.0 to 5.5. Under these conditions, the undissociated permeating form is predominant (compounds 11a and 11b) or is poorly represented (compounds 7 and 9). This means that other factors determined biological activity. 


\subsection{Predicting phloem mobility of fenpiclonil derivatives and evaluation of systemicity of}

\section{compound 9}

In the last decade, models based on the physico-chemical properties of pesticides have been put forward to predict their phloem mobility. ${ }^{1,4,6}$ With the exception of a few products, including xenobiotics whose transport is carrier-mediated, ${ }^{31}$ much of the data on xenobiotic transport in plants fits well into these schemes. ${ }^{4,6}$ Phloem mobility for fenpiclonil and its analogues was predicted using the Kleier map (Table 1, Fig 5). ${ }^{6}$ The fenpiclonil acidic derivatives range into the areas of the moderately phloem mobile compounds though the lipophilicity of fenpiclonil itself appears inconsistent with phloem systemicity.

We have studied the phloem mobility of compound 9 because it is located in the moderately phloem-mobile area. To evaluate phloem mobility, we used the castor bean system, a biological model widely employed in the recent past to study phloem sap composition and transport properties of nutrients. ${ }^{28,32,33}$ The castor bean is also very useful to study the phloem mobility of xenobiotics. ${ }^{8,29}$ However, this model is reliable only if the xenobiotics tested are not phytotoxic under these short-term experiments, particularly if they do not depolarize the transmembrane PD. Values of the transmembrane PD are a good indicator of the activity of plasma membrane proton-pumping ATPase which energizes secondary translocation of nutrients and maintains acidic molecule influx through the lipid bilayer. ${ }^{4,6,10}$ Compound 9 has no depolarizing effect on the transmembrane PD (Fig 6). On the one hand, the transmembrane PD of subepidermal cells of the hook is close to $-100 \mathrm{mV}$ both in the control and that incubated with compound 9 at $250 \mu \mathrm{M}$ immediately after isolation of the upper part of the young plant (cotyledons and hook). On the other hand, hyperpolarization of transmembrane PD which takes place during the phenomenon of ageing is the same in the two sets. The transmembrane PD reaches values close to $-150 \mathrm{mV}$ after $5 \mathrm{~h}$ of incubation. These results deserve to be compared with those obtained with fenpiclonil. Although this fungicide enhances the accumulation of tetraphenylphosphonium bromide $\left(\mathrm{TPP}^{+}\right)$in Fusarium sulphureum cells, it does not seem to affect the functioning of the plasma membrane. The increased accumulation of $\mathrm{TPP}^{+}$caused by fenpiclonil probably reflects changes in potentials over membranes of intracellular organelles rather than that of 
the plasma membrane..$^{30}$ Our results indicate that the Ricinus system is suitable for testing the phloem systemicity of fenpiclonil acid derivatives.

When Ricinus cotyledons were incubated in the presence of $250 \mu \mathrm{M}$ fenpiclonil, the fungicide was not detected in the phloem sap. ${ }^{29}$ By contrast, when cotyledons were incubated in an acidic solution with compound 9 at the same concentration, the derivative was clearly found in the phloem sap (Fig 7). These data are consistent with the above predictions (Fig 5). Furthermore, in the latter experiment, fenpiclonil, the parent molecule, was not detected in the phloem sap, indicating that compound 9 does not undergo loss of the $N$-carboxymethyl group to any significant extent in the sieve element-companion cell complex. In a recent past, it has been observed that the fungicidal activity of some N-substituted derivatives of the 3-cyano-4-phenylpyrroles was dependent on their ability to release the parent compound. ${ }^{17}$ If this is also relevant to our acidic derivatives (in that case the products could be degraded by the fungus), then compound 9 can be considered as a phloem mobile profungicide.

As Ricinus is a symplastic-apoplastic loader, ${ }^{32}$ compound 9 molecules moving in the sieve-tubes may be taken up from the phloem apoplast or may come from the mesophyll and especially the cotyledon epidermis via the symplastic route. But in the latter case, the xenobiotic must also cross the plasma membrane. Time-course experiments have indicated that compound $\mathbf{9}$ concentration in the phloem sap increased linearly for a few hours before reaching a plateau (Fig 8 A and B). Also the xenobiotic loading was much faster and greater under the most acidic incubation condition (Fig 8 B). This strongly indicates that compound 9 uptake is $\mathrm{pH}$-dependent and Fig 9 shows that it is indeed the case. The fungicide derivative was not taken up at neutral and alkaline $\mathrm{pH}$ values. Its concentration in the phloem sap was clearly correlated to the percentage of the undissociated form in the incubation solution and was maximal at the most acidic $\mathrm{pH}$ value. Thus compound $\mathbf{9}$ uptake is due to passive transport of the lipophilic form through the plasma membrane. Subsequent dissociation, especially inside the symplastic phloem compartment, to the poorly permeating anion leads to long-distance transport, as already described for acidic herbicides. ${ }^{1,4,6,8,10}$ Compound $\mathbf{9}$ concentration in the phloem sap was 0.15 - and 0.40 -fold that of the incubation solution buffered at $\mathrm{pH} 5.0$ and 4.6 respectively. 
These values were much lower than those already noted when testing acidic herbicides, especially 2,4$\mathrm{D}(10 \text {-fold })^{8,29}$ which is taken up by two mechanisms, the ion-trap mechanism and an active carriermediated process. ${ }^{11,12}$ However, they were similar to that found in studies of the phloem mobility of the herbicide glyphosate (0.2-fold) under similar experimental conditions. ${ }^{29}$

\section{CONCLUSION}

A series of derivatives of fenpiclonil was synthesized containing a carboxyl group at various sites on the benzene or pyrrole rings. Taking into account their physico-chemical properties, all these acidic derivatives were predicted to be moderately phloem-mobile but the group of $\mathrm{N}$-substituted fenpiclonil derivatives, particularly $\mathrm{N}$-carboxymethyl-3-cyano-4-(2,3-dichlorophenyl)pyrrole (compound 9), received special attention because it exhibited some activity on Eutypa lata, a pathogenic fungus located in the vascular system of various plant species.

Systemicity tests using the Ricinus system demonstrated that, unlike fenpiclonil, compound 9 does move in the phloem without being degraded in detectable amounts. This indicates that this derivative is relatively stable, which facilitates export out of the leaf tissues and long-distance transport within the plant. In addition, the close correlation between the concentration of compound 9 in the phloem sap and the concentration of the permeating (i.e. undissociated) form of the molecule in the external medium indicates that systemicity is due to the ion-trap mechanism.

\section{ACKNOWLEDGEMENTS}

We are grateful to the Conseil Interprofessionnel du Vin de Bordeaux for the financial support of this work. The authors are indebted to two anonymous referees for constructive criticism. 


\section{REFERENCES}

(1) Kleier DA, Phloem mobility of xenobiotics. I. Mathematical model unifying the weak acid and intermediate permeability theories, Plant Physiol 86:803-810 (1988)

(2) Hsu FC, Kleier DA and Melander WR, Phloem mobility of xenobiotics. II. Bioassay testing of the unified mathematical model. Plant Physiol 86:811-816 (1988)

(3) Bromilow RH, Chamberlain K and Evans AA, Physicochemical aspects of phloem translocation of herbicides. Weed Sci 38:305-314 (1990)

(4) Bromilow RH, Chamberlain K and Evans AA, Molecular structure and properties of xenobiotics in relation to phloem translocation, in Recent advances in phloem transport and assimilate compartmentation, ed by Bonnemain JL, Delrot S, Lucas WJ and Dainty J, Ouest Editions, Presses Academiques, Nantes, pp 332-340 (1991)

(5) Grimm E, Grube A, Jahnke S and Neumann S, Retention of xenobiotics along the phloem path. Planta 197:11-18 (1995)

(6) Kleier DA, Grayson BT and Hsu FC, The phloem mobility of pesticides, Pesticide Outlook, 26$30(1998)$

(7) Tyree MT, Peterson CA and Edgington LV, A simple theory regarding ambimobility of xenobiotics with special reference to the nematicide, oxamyl. Plant Physiol 63:367-374 (1979)

(8) Rigitano RLO, Bromilow RH, Briggs GG and Chamberlain K, Phloem translocation of weak acids in Ricinus communis. Pestic Sci 19:113-133 (1987)

(9) Bromilow RH and Chamberlain K, Designing molecules for systemicity, in Mechanisms and regulation of transport process. Monograph 18, ed by Atkin RK and Clifford DR, British Plant Growth Regulator Group, Bristol, pp 113-128 (1989)

(10) Delrot S and Bonnemain JL, Absorption et migration des herbicides, in Les herbicides, mode d'action et principes d'utilisation. Institut National de la Recherche Agronomique, Paris, pp 51$77(1991)$

(11) Kasai F and Bayer DE, Quantitative evaluation of the weak acid hypothesis as the mechanism for 2,4-D absorption by corn root protoplasts. J. Pesticide Science 16:163-170 (1991) 
(12) Chen L, Ortiz-Lopez A, Jung A and Bush DR, ANT1, an aromatic and neutral amino acid transporter in Arabidopsis. Plant Physiol 125:1813-1820 (2001)

(13) Edgington LV, Structural requirements of systemic fungicides. Ann. Rev. Phytopathol. 19:107$214(1981)$

(14) Leroux P, Delorme R and Gaillardon P, Évolution des produits phytosanitaires à usages agricoles II-Les fongicides. Phytoma 545:8-15 (2002)

(15) Zaki AI, Zentmyer GA and Le Baron HM, Systemic translocation of ${ }^{14} \mathrm{C}$-labeled metalaxyl in tomato, avocado, and Persea indica. Phytopathology 71:509-514 (1981)

(16) Nevill D, Nyfeler R and Sozzi D, CGA 142705: a novel fungicide for seed treatment, Brighton Crop Protection Conference, Pests and Diseases 1:65-72 (1988)

(17) Nyfeler R and Ackermann P, Phenylpyrroles, a new class of agricultural fungicides related to the natural antibiotic pyrrolnitrin, in Synthesis and Chemistry of Agrochemicals III, ed by Baker DR, Fenyes JG and Steffens JJ, American Chemical Society, Washington, USA, pp 395-404 (1992)

(18) Gehmann K, Nyfeler R, Leadbeater AJ, Nevill D and Sozzi D, CGA 173506: a new phenylpyrrole fungicide for broad-spectrum disease control, Brighton Crop Conf. Pests Dis. 1990, 2, $399(1990)$

(19) Ackermann P, Ehrenfreund J, Nyfeler R and Martin P, Mikrobizide mittel. Eur. Pat. Appl. EP $0310558(1989)$

(20) Wollweber D and Brandes W, 1-Aminomethyl-3-(2-fluor-3-chlorphenyl)-4-cyano-pyrrolDerivate. Eur. Pat. EP 0327977 (1989)

(21) Froyd JD and Smith DB, Method of controlling phytopathogenic fungi. Eur. Pat. Appl. EP $0358047(1990)$

(22) Gribble GW, Keavy DJ, Davis DA, Saulnier MG, Pelcman B, Barden TC, Sibi MP, Olson ER and Belbruno JJ, Syntheses and Diels-Alder cycloaddition reactions of $4 H$-furo[3,4-b] indoles. A regiospecific Diels-Alder synthesis of ellipticine. J Org Chem 57:5878-5891 (1992) 
(23) Dean PDG, Halogenolysis of methyl glycyrrhetate with lithium iodide - dimethylformamide. $J$ Chem Soc, 6655 (1965)

(24) Mc Murry JE et Wong GB, An improved method for the cleavage of methyl esters. Synth Commun 2:389-394 (1972)

(25) Van Reet G, Heeres J and Wals L, 1-(ß-Aryl)-äthyl-1H-1,2,4-triazolketale und ihre Salze, Verfahren zu ihrer Herstellung und fungizide Mittel und pflanzenwuehsregulierende Mittel. Ger Offen DE 2551560 (1976)

(26) Gershon H, Shapira J, Meek JS and Dittmer K, The syntheses and microbiological properties of acetylenic amino acids - Propargyl glycine and 2-amino-3-methyl-4-pentynoic acid. J Am Chem Soc 76:3484-3486 (1954)

(27) Mounoury G, Delrot S and Bonnemain JL, Energetics of threonine uptake by pod wall tissues of Vicia faba L.. Planta 161:178-185 (1984)

(28) Kallarackal J, Orlich G, Schobert C and Komor E, Sucrose transport into the phloem of Ricinus communis L. seedlings as measured by the analysis of sieve-tube sap. Planta 177:327-335 (1989)

(29) Delétage-Grandon C, Chollet JF, Faucher M, Rocher F, Komor E, and Bonnemain JL, Carriermediated uptake and phloem systemy of a 350-Dalton chlorinated xenobiotic with an $\alpha$-amino acid function. Plant Physiol 125:1620-1632 (2001)

(30) Jespers Ad BK, Davidse LC and De Waard MA, Interference of the phenylpyrrole fungicide fenpiclonil with membranes and membrane function. Pestic Sci 40:133-140 (1994)

(31) Wright KM and Oparka KJ, Physicochemical properties alone do not predict the movement and compartmentation of fluorescent xenobiotics. J. Exp. Bot. 45:35-44 (1994)

(32) Orlich G and Komor E, Phloem loading in Ricinus cotyledons: sucrose pathways via the mesophyll and the apoplasm. Planta 187:460-474 (1992)

(33) Schobert C and Komor E, The differential transport of amino acids into the phloem of Ricinus communis L. seedlings as shown by the analysis of sieve-tube sap. Planta 177: 342-349 (1989) 
Table 1 : Predicted $\mathrm{pKa}$ and $\log \mathrm{K}_{\mathrm{ow}}$ values of the products using ACD Log D v. 7.0 software

\begin{tabular}{|c|c|c|}
\hline Product & pKa & $\log \mathbf{K}_{\mathbf{o w}}$ \\
\hline $4 \mathrm{a}$ & 4.01 & 2.82 \\
\hline $4 \mathrm{~b}$ & 3.68 & 1.98 \\
\hline $4 \mathrm{c}$ & 2.75 & 2.85 \\
\hline 7 & 1.83 & 3.93 \\
\hline 9 & 2.44 & 2.63 \\
\hline $11 \mathrm{a}$ & 3.81 & 2.80 \\
\hline $11 \mathrm{~b}$ & 4.44 & 3.07 \\
\hline fenpiclonil & 13.63 & 3.88 \\
\hline
\end{tabular}



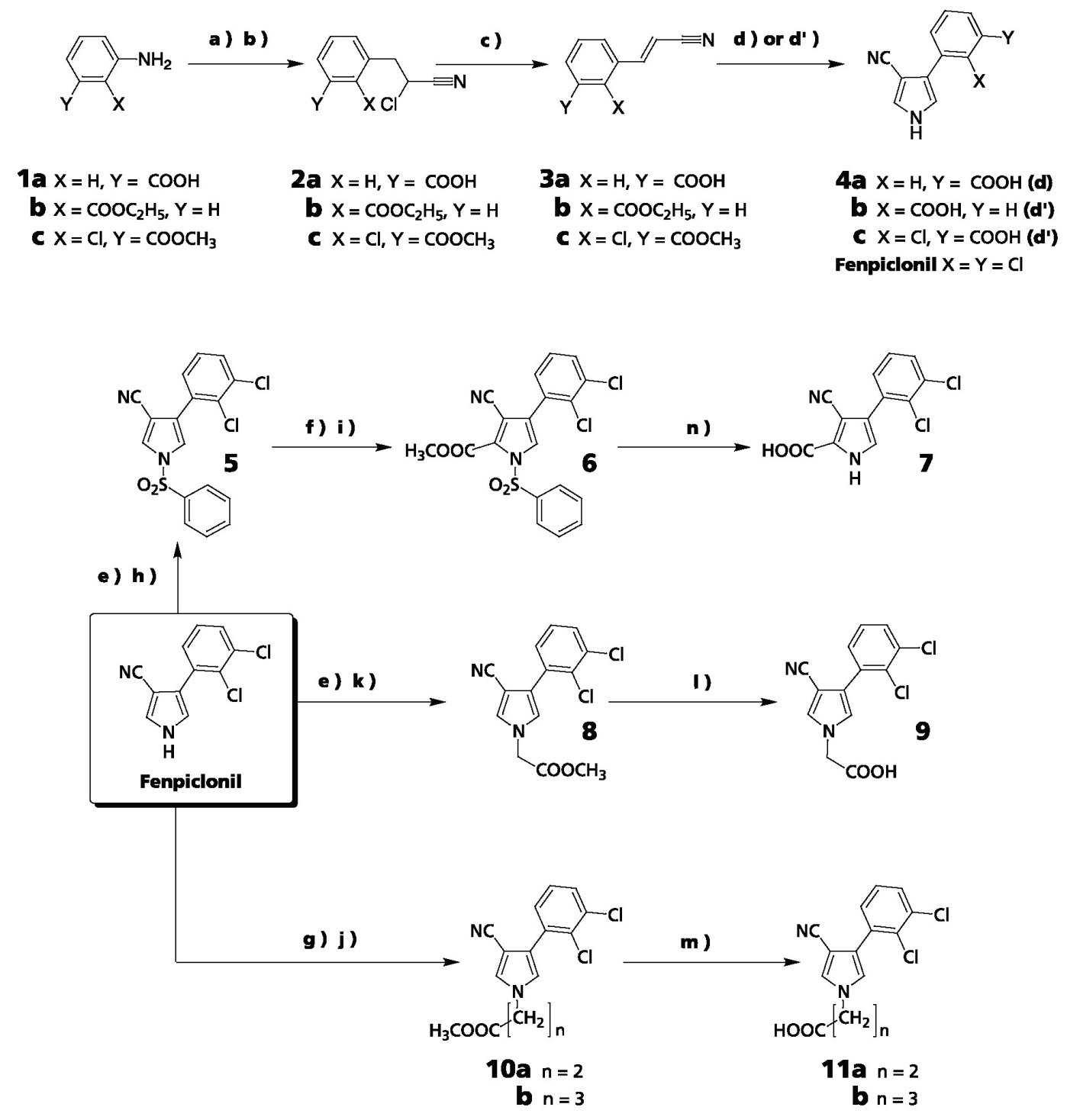

Figure 1. General reaction scheme. a) $\mathrm{NaNO}_{2} / \mathrm{CH}_{3} \mathrm{COOH}, \mathrm{HCl} 12 \mathrm{M}, \mathrm{H}_{2} \mathrm{O} / 2 \mathrm{~h} 30,0^{\circ} \mathrm{C}$; b) $\mathrm{CH}_{2}=\mathrm{CHCN} /$ acetone $/ 20^{\circ} \mathrm{C}$ then $\mathrm{CuCl} / \mathrm{HCl} 12 \mathrm{M} / 30 \mathrm{~min}, 40^{\circ} \mathrm{C}$; c) 1,8-diazabicyclo[5-4-0] undec5-ene (DBU) / THF / $15 \mathrm{~h}, 20^{\circ} \mathrm{C}$; d) Tosylmethyl isocyanide (TosMIC), NaH 2.4 eq / diethyl ether, DMSO / $1 \mathrm{~h}, 20^{\circ} \mathrm{C}$; d') idem d) but $\mathrm{NaH} 3.5 \mathrm{eq} / 3 \mathrm{~h}, 20^{\circ} \mathrm{C}$ then $2 \mathrm{~h}, 34^{\circ} \mathrm{C}$; e) $\mathrm{nBuLi} / \mathrm{THF} / 3 \mathrm{~h}, 0^{\circ} \mathrm{C} ; \mathbf{f}$ ) LDA / THF / $1 \mathrm{~h},-80^{\circ} \mathrm{C} ;$ g) $\mathrm{CH}_{3} \mathrm{ONa}, \mathrm{CH}_{3} \mathrm{OH} / \mathrm{DMF} / 3 \mathrm{~h}, 20^{\circ} \mathrm{C} ;$ h) $\mathrm{ClSO}_{2} \mathrm{C}_{6} \mathrm{H}_{5} / 2 \mathrm{~h}, 0^{\circ} \mathrm{C}$ then $15 \mathrm{~h}$, $20^{\circ} \mathrm{C}$; i) $\mathrm{ClCOOCH}_{3} ; 5 \mathrm{~h},-80^{\circ} \mathrm{C}$ then $15 \mathrm{~h},-80^{\circ} \mathrm{C}$ to $20^{\circ} \mathrm{C}$; j) $\mathrm{Br}_{(}\left(\mathrm{CH}_{2}\right)_{n} \mathrm{COOCH}_{3}, \mathrm{NaI} / \mathrm{DMF} / \mathrm{n}=2$, 24h, $100^{\circ} \mathrm{C} ; \mathrm{n}=3,10 \mathrm{~h}, 120^{\circ} \mathrm{C}$; k) $\mathrm{BrCH}_{2} \mathrm{COOCH}_{3} / 3 \mathrm{~h}, 0^{\circ} \mathrm{C}$ then $\left.15 \mathrm{~h}, 20^{\circ} \mathrm{C} ; \mathrm{l}\right) \mathrm{LiI} / \mathrm{DMF} / 18 \mathrm{~h}$, reflux; m) $\mathrm{NaOH} 1.25 \mathrm{M}$ in water $/ \mathrm{C}_{2} \mathrm{H}_{5} \mathrm{OH} / 1 \mathrm{~h}, 20^{\circ} \mathrm{C}$ then $1 \mathrm{~h}, 60^{\circ} \mathrm{C}$; n) $\mathrm{NaOH} 8 \mathrm{M}$ in water $/ \mathrm{THF} / \mathrm{CH}_{3} \mathrm{OH}$ $/$ reflux $48 \mathrm{~h}$ 


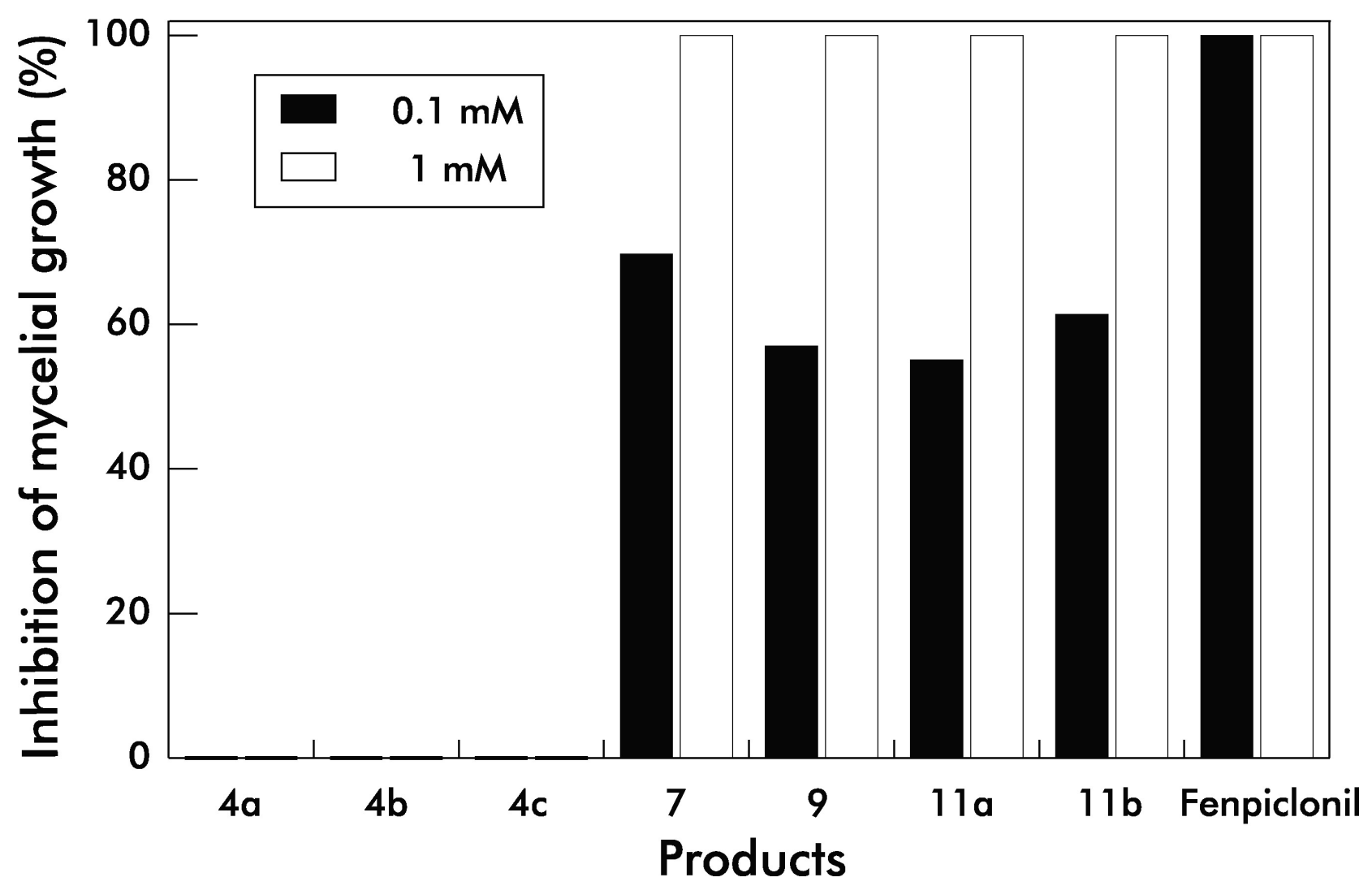

Figure 2. Short-term effect (7 days culture) of fenpiclonil and its acidic derivatives on E. lata mycelial growth (mean of 6 wells, SD were negligible) 

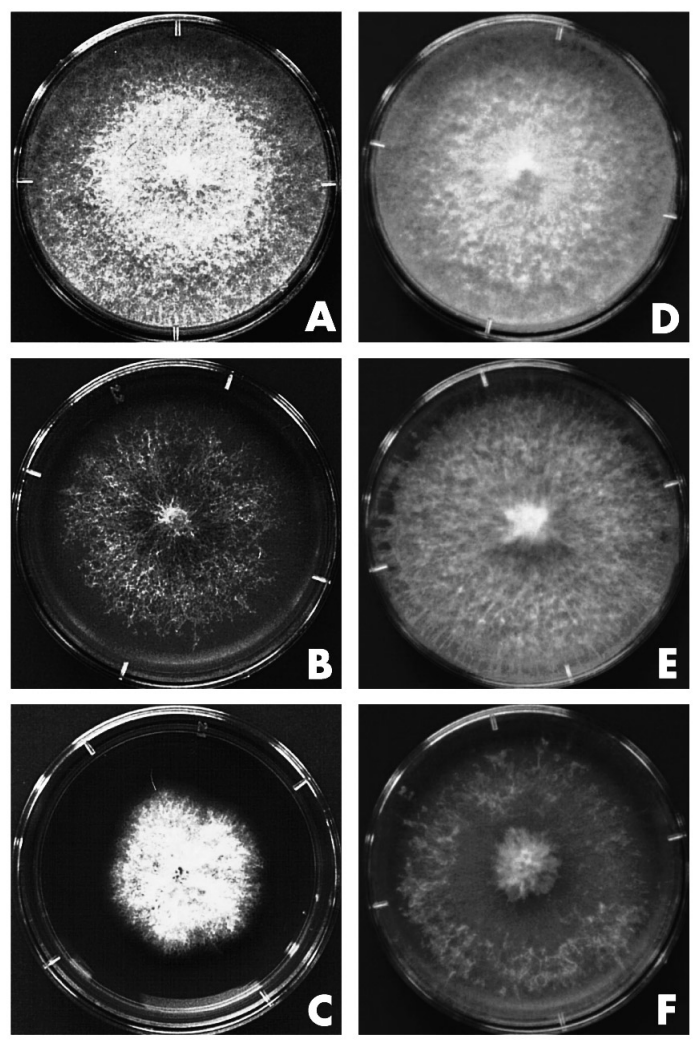

Figure 3. Long-term effect (21 days culture) of fenpiclonil (A, B, C) and compound 9 (D,E,F) on $E$. lata mycelial growth. The products were used at $0 \mathrm{mM}(\mathrm{A}, \mathrm{D}), 10 \mu \mathrm{M}(\mathrm{B}, \mathrm{E})$ and $50 \mu \mathrm{M}(\mathrm{C}, \mathrm{F})$ concentration. Note the mycelium necrosis around the inoculum in B and F. The experiment was repeated 6 times with similar results. 


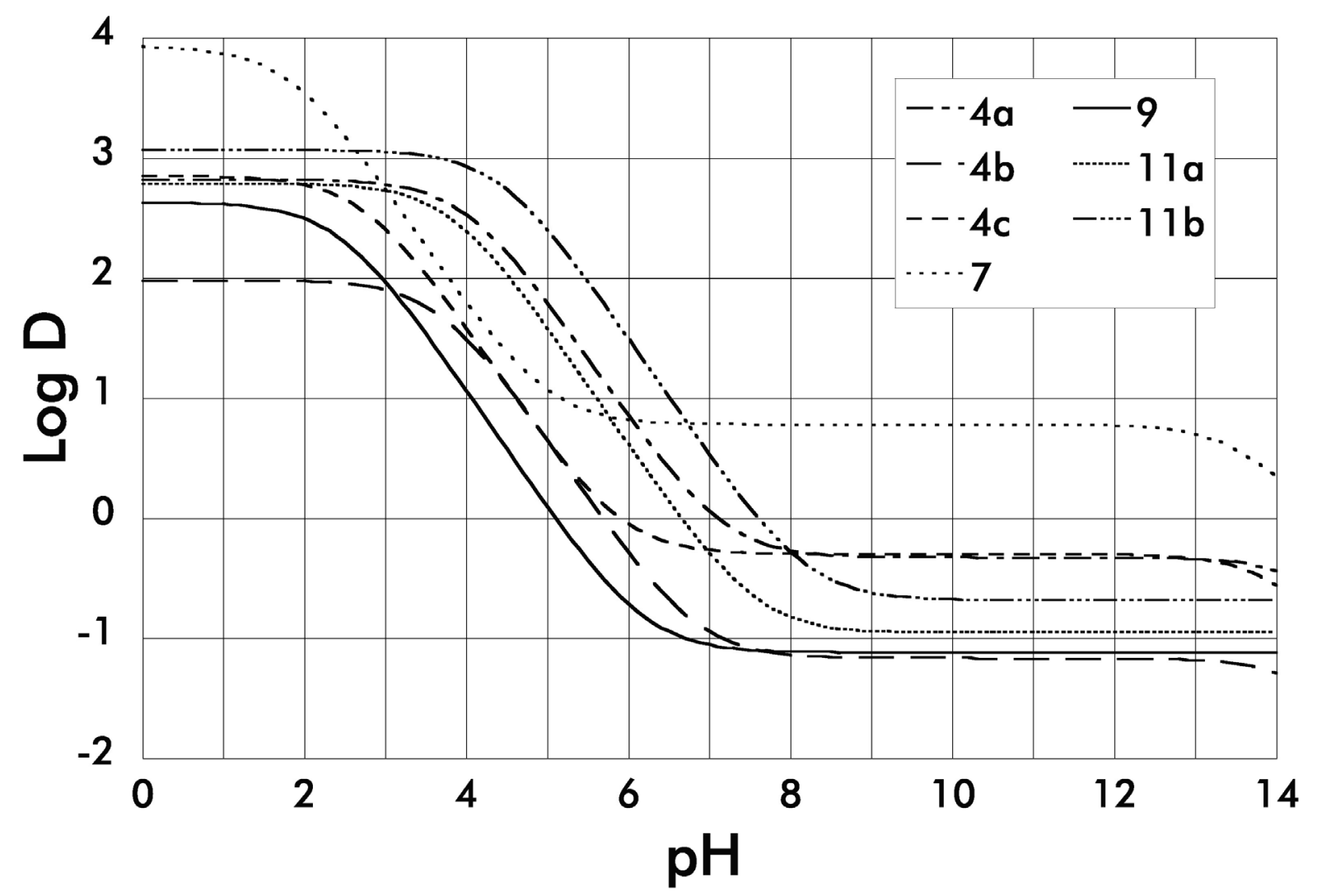

Figure 4. Dependence of $\log \mathrm{D}$ of the various acidic derivatives on $\mathrm{pH}$ (calculated using ACD Log D v. 7.0 software). The partition coefficient for dissociative mixtures, $\log \mathrm{D}$, is defined as follows:

$$
\log D=\log \left(\frac{\sum a_{i}^{\text {org }}}{\sum a_{i}^{H 2 O}}\right)
$$

where $\quad a_{i}^{H 2 O}$ is the concentration of $\mathrm{i}$-th microspecies in water

$a_{i}^{\text {org }}$ is the concentration of $\mathrm{i}$-th microspecies in organic phase 

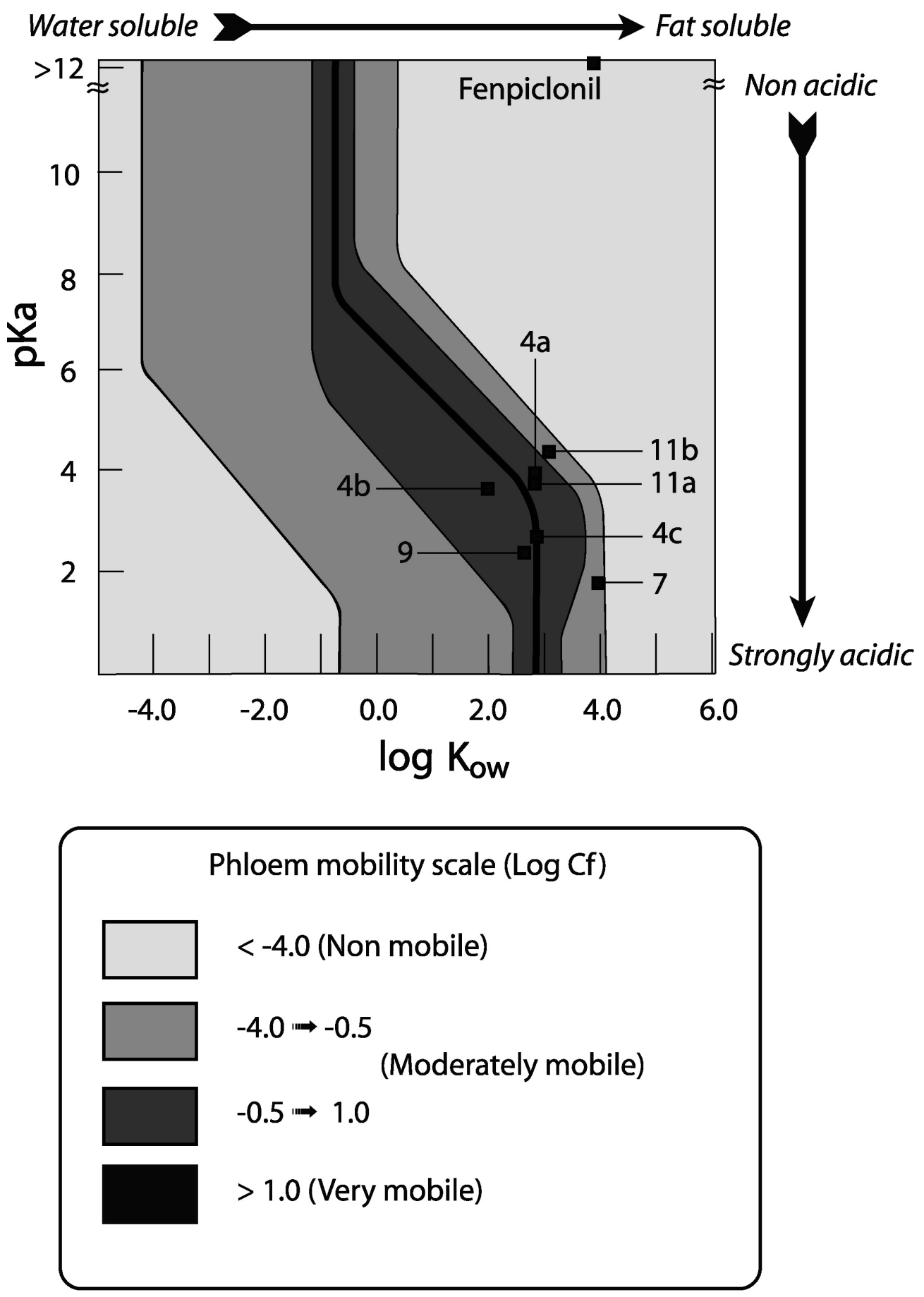

Figure 5. Prediction of phloem mobility of fenpiclonil and its acidic derivatives using the Kleier map ( $\log \mathrm{Cf}$ as a function of $\log \mathrm{K}_{\mathrm{ow}}$ and $\mathrm{pKa}$ ). $\log \mathrm{K}_{\mathrm{ow}}$ and $\mathrm{pKa}$ were calculated using ACD Log D v. 7.0 software (see table 1). Plant parameters are given in Kleier $1988^{1}$. 


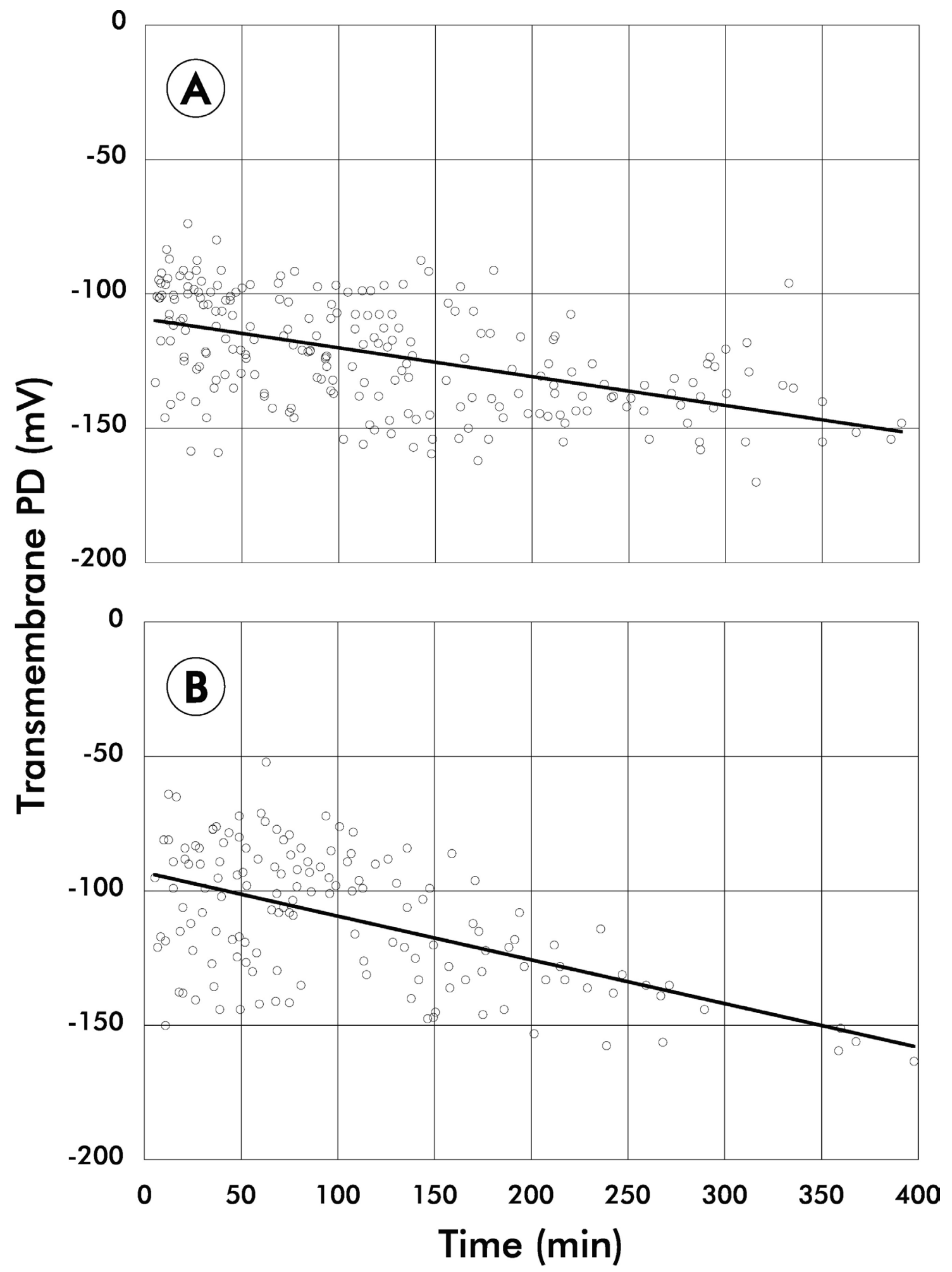

Figure 6. Effect of compound 9 on the transmembrane PD of subepidermal cells of Ricinus hook. A : control, the tissues were incubated in the standard medium $(\mathrm{pH} \mathrm{5.0)}$; $\mathrm{B}$ : treated set, the tissues were incubated in the same solution with compound 9 at $250 \mu \mathrm{M}$ concentration. Linear regression was calculated with Kaleidagraph v. 3.5 software. 


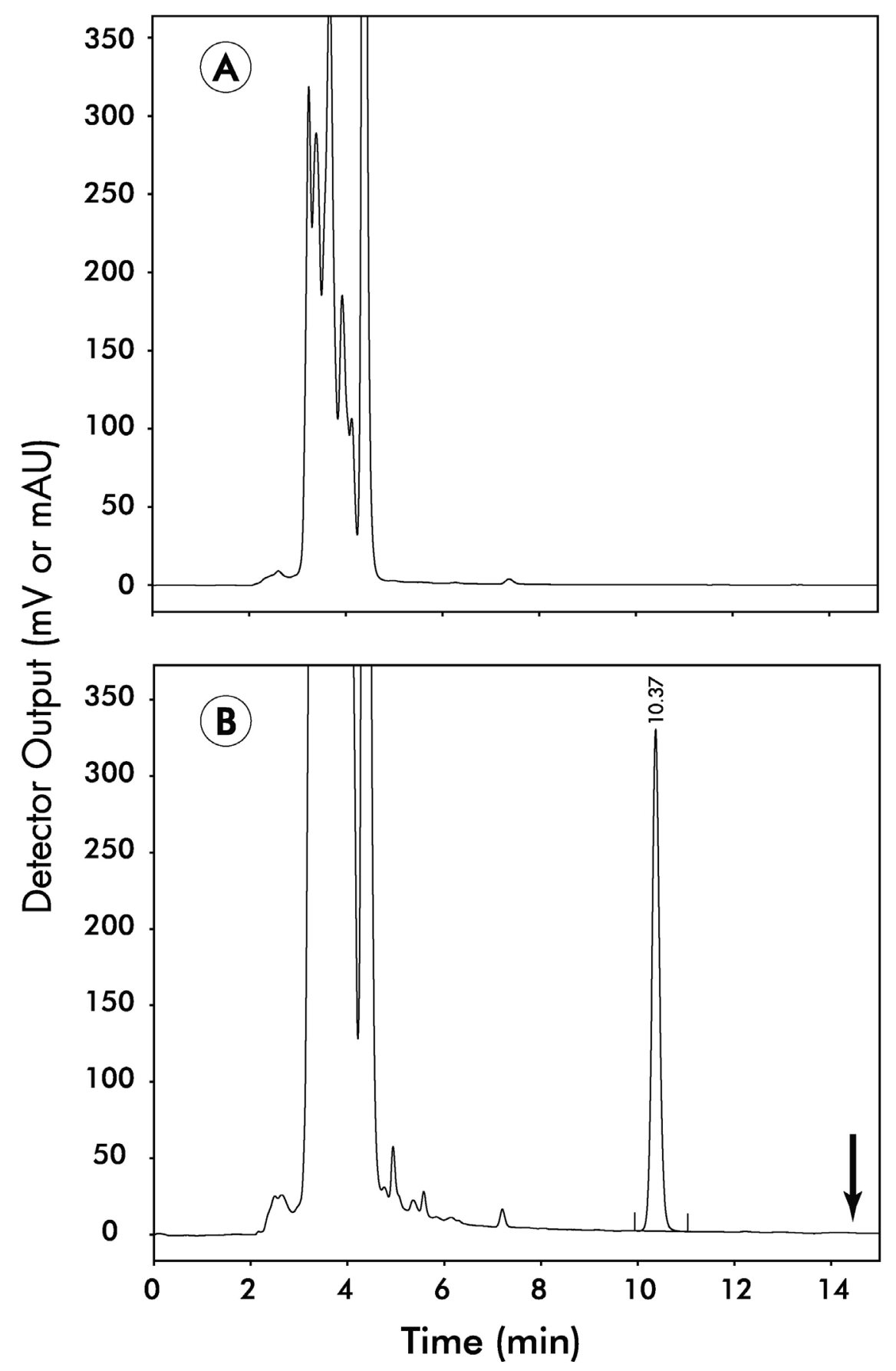

Figure 7. Ricinus sap analysis by HPLC. A : control, the cotyledons were incubated in the standard medium ( $\mathrm{pH}$ 5.0); B : treated set, Ricinus cotyledons were incubated in the same solution with compound 9 (RT : $10.37 \mathrm{~min}$ ) at $250 \mu \mathrm{M}$ concentration. The arrow indicates the retention time of fenpiclonil. 

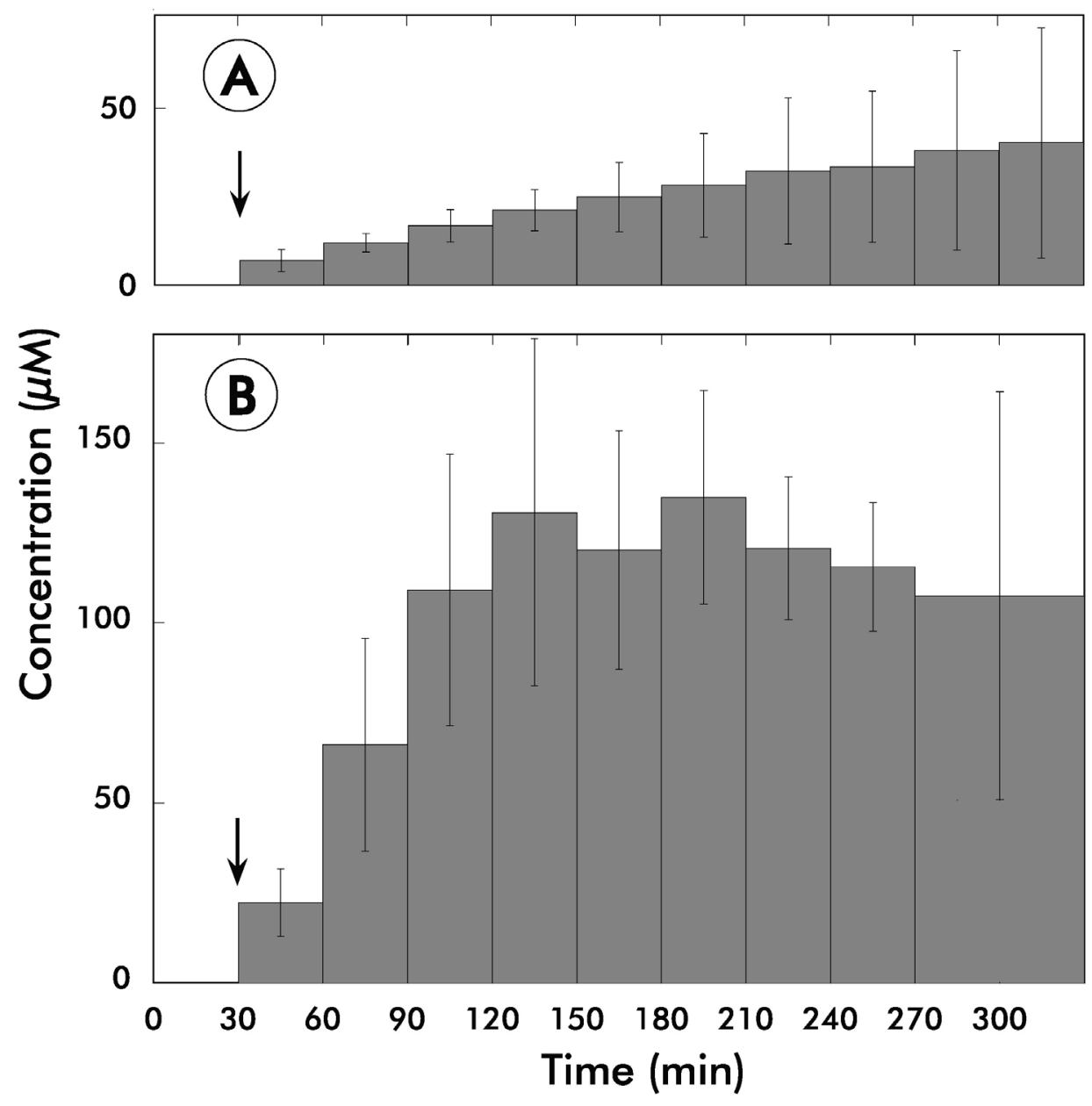

Figure 8. Time course of compound $\mathbf{9}$ concentration in phloem sap of Ricinus. At time 0 , compound 9 at $250 \mu \mathrm{M}$ concentration was added to the standard medium buffered at $\mathrm{pH} 5.0$ (A) or 4.6 (B). The hook was severed at time $30 \mathrm{~min}$ (arrow). Mean of 6 sets of 6 plants \pm SD (A); mean of 5 sets of 3 plants \pm SD (B). 


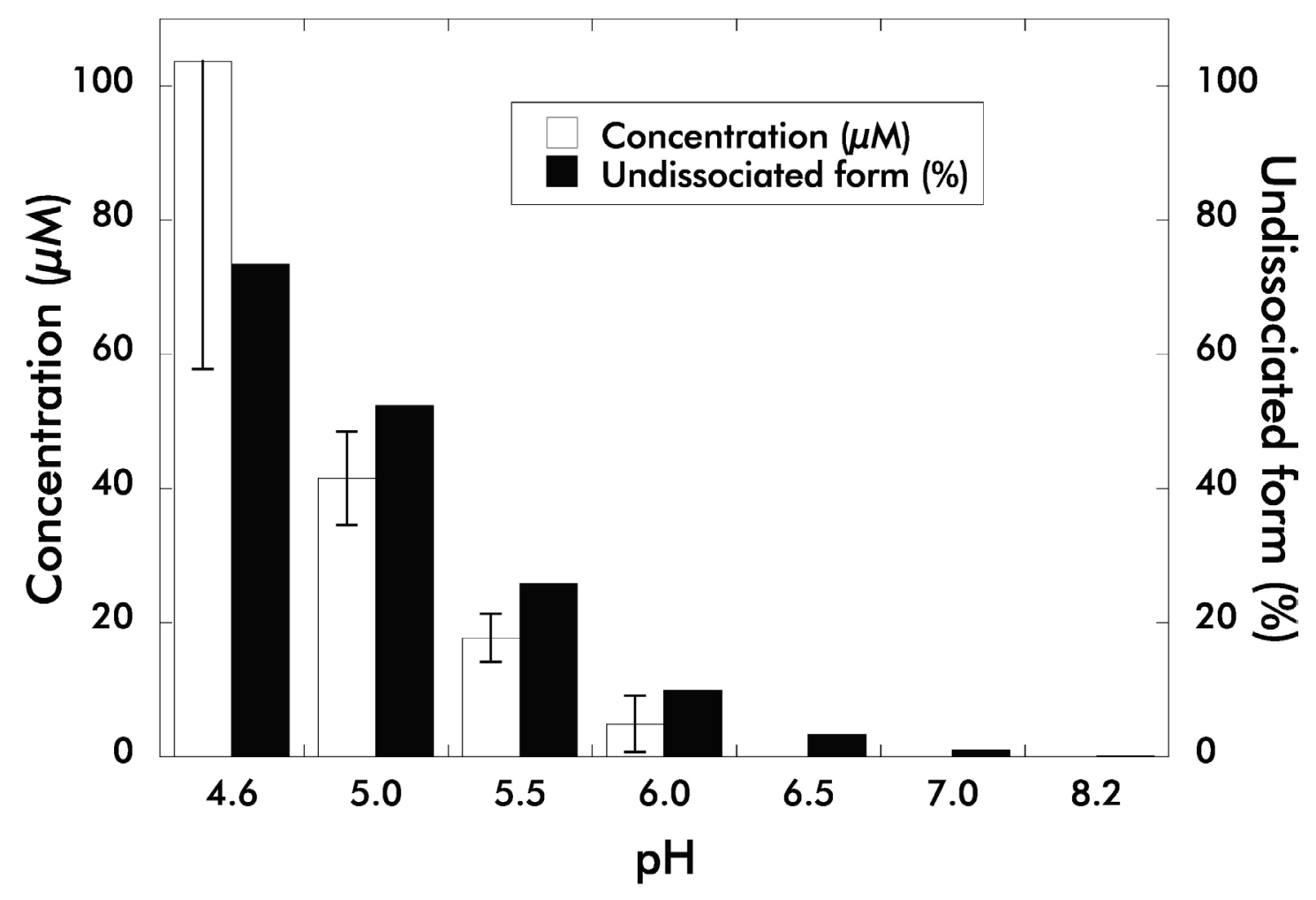

Figure 9. Concentration of compound 9 (applied at $250 \mu \mathrm{M}$ concentration to the external solution) in phloem sap of Ricinus as a function of the $\mathrm{pH}$ of the incubation medium and the percentage of its undissociated form in this medium. The sap was collected during the third and fourth hours of incubation. Mean of 8 sets of 3 plants ( $\mathrm{pH} 4.6$ ) or 3 sets of 3 plants (other $\mathrm{pH}$ values) \pm SD. 